\title{
Development of Green Storable Hybrid Rocket Propulsion Technology Using 98\% Hydrogen Peroxide as Oxidizer
}

\author{
Adam Okninski *(D), Pawel Surmacz (D), Bartosz Bartkowiak, Tobiasz Mayer, Kamil Sobczak, Michal Pakosz, \\ Damian Kaniewski D, Jan Matyszewski, Grzegorz Rarata and Piotr Wolanski
}

\author{
Lukasiewicz Research Network-Institute of Aviation, Al. Krakowska 110/114, 02-256 Warsaw, Poland; \\ pawel.surmacz@ilot.lukasiewicz.gov.pl (P.S.); bartosz.bartkowiak@ilot.lukasiewicz.gov.pl (B.B.); \\ tobiasz.mayer@ilot.lukasiewicz.gov.pl (T.M.); kamil.sobczak@ilot.lukasiewicz.gov.pl (K.S.); \\ michal.pakosz@ilot.lukasiewicz.gov.pl (M.P.); damian.kaniewski@ilot.lukasiewicz.gov.pl (D.K.); \\ jan.matyszewski@ilot.lukasiewicz.gov.pl (J.M.); grzegorz.rarata@ilot.lukasiewicz.gov.pl (G.R.); \\ piotr.wolanski@ilot.lukasiewicz.gov.pl (P.W.) \\ * Correspondence: adam.okninski@ilot.lukasiewicz.gov.pl; Tel.: +48-22-846-00-11 (ext. 331)
}

check for updates

Citation: Okninski, A.; Surmacz, P.; Bartkowiak, B.; Mayer, T.; Sobczak, K.; Pakosz, M.; Kaniewski, D.; Matyszewski, J.; Rarata, G.; Wolanski, P. Development of Green Storable Hybrid Rocket Propulsion Technology Using 98\% Hydrogen Peroxide as Oxidizer. Aerospace 2021, 8, 234. https://doi.org/10.3390/ aerospace 8090234

Academic Editors: Toru Shimada, Arif Karabeyoglu and Carmine Carmicino

Received: 20 June 2021

Accepted: 10 August 2021

Published: 24 August 2021

Publisher's Note: MDPI stays neutral with regard to jurisdictional claims in published maps and institutional affiliations.

Copyright: (c) 2021 by the authors. Licensee MDPI, Basel, Switzerland. This article is an open access article distributed under the terms and conditions of the Creative Commons Attribution (CC BY) license (https:/ / creativecommons.org/licenses/by/ $4.0 /)$.
Abstract: This paper presents the development of indigenous hybrid rocket technology, using 98\% hydrogen peroxide as an oxidizer. Consecutive steps are presented, which started with interest in hydrogen peroxide and the development of technology to obtain High Test Peroxide, finally allowing concentrations of up to $99.99 \%$ to be obtained in-house. Hydrogen peroxide of $98 \%$ concentration (mass-wise) was selected as the workhorse for further space propulsion and space transportation developments. Over the course nearly 10 years of the technology's evolution, the Lukasiewicz Research Network-Institute of Aviation completed hundreds of subscale hybrid rocket motor and component tests. In 2017, the Institute presented the first vehicle in the world to have demonstrated in-flight utilization for $98 \%$ hydrogen peroxide. This was achieved by the ILR-33 AMBER suborbital rocket, which utilizes a hybrid rocket propulsion as the main stage. Since then, three successful consecutive flights of the vehicle have been performed, and flights to the Von Karman Line are planned. The hybrid rocket technology developments are described. Advances in hybrid fuel technology are shown, including the testing of fuel grains. Theoretical studies and sizing of hybrid propulsion systems for spacecraft, sounding rockets and small launch vehicles have been performed, and planned further developments are discussed.

Keywords: hybrid rocket propulsion; hybrid rocket motor; hydrogen peroxide; High Test Peroxide (HTP); hybrid rocket fuel; additive manufacturing; regression rate; sounding rocket; suborbital flight; space transportation

\section{Introduction}

While the development of hybrid rocket technology has a nearly 90-year history, it has led to a very limited number of operational systems [1,2]. This is due to challenges in hybrid propulsion modeling, system up-scaling and low Technology Readiness Levels when compared to parallel rapid advances in the field of solid and liquid rocket propulsion. Development challenges and advantages of hybrid rocket propulsion are discussed in [3,4]. Major work in the early decades was conducted in the Soviet Union, Germany, the United States, Sweden, India and France. More on the evolution of the technology in its early decades, when less knowledge on burn rate modeling and its enhancement was present, can be found in [5-8]. Recent advances led to increased interest in hybrid rocket systems [9-11]. In the 21st century, hybrid propulsion became an attractive solution for various technology applications, often not envisaged earlier. Its high performance, low complexity and acceptable cost, robustness and motor restartability make it an option considered in most early-phase chemical propulsion system trade-offs. Hybrid rocket motors are widely considered for inter alia suborbital flight [2], launch vehicles [12], kick-stages [13], exploration 
missions [14] (including ascent [15] and lander descent elements [16]) and for satellite platforms [17]. In the latter case, this technology may be applied to satellites of various sizes and missions-including apogee propulsion, space tugs, as well as deorbitation motors, which are discussed further within this paper. While experimental research in the field of hybrid propulsion has been undertaken in dozens of countries worldwide, a partial shift in development focus to motors using oxidizers requiring relatively simple operations can be seen.

While LOX remains an attractive solution for several hybrid rocket propulsion applications, the fact that it may complicate vehicle operation and increase the required ground infrastructure has limited its potential use mostly to systems where high performance is needed. This solution is not attractive for any long-duration missions, including spacecraft applications, due to the cryogenic properties of LOX and its limited in-space storability. Very high specific impulse systems using liquid fluorine in combination with LOX (FLOX) have been also historically tested in the United States [6] and Germany [18,19], but they have, thus far, not been investigated experimentally or discussed in the modern literature due to handling issues. Toxic storable oxidizers including $\mathrm{N}_{2} \mathrm{O}_{4}$ and $\mathrm{HNO}_{3}$ have been used for hybrid propulsion systems in the past [20], but they are not of significant interest nowadays due to environmental issues and safety challenges. An oxidizer of limited interest in the initial decades of hybrid rocket propulsion development was $\mathrm{N}_{2} \mathrm{O}$. However, increased efforts can be seen in recent years due to its relative ease of handling and self-pressurization capability. It is, however, rarely considered for use in launch vehicles (despite some examples: [21]) due to low performance. It is mostly implemented in suborbital vehicles [2,22,23], commonly being used by student and hobbyist rocketry groups [24]. The limited heritage and thermal sensitivity make it a rare choice for satellite propulsion developments. Despite its common utilization by groups with a very wide range of experience, it requires specific efforts to ensure safe handling [25]. Another oxidizer solution considered for hybrid rocket motors is NYTROX-a mixture of $\mathrm{N}_{2} \mathrm{O}$ and GOX [26]. This allows for higher systemspecific impulse and the minimum ignition energy can be increased in comparison to pure $\mathrm{N}_{2} \mathrm{O}$ systems, which increases the safety of its handling. To date, there is no information on flight-operational systems using NYTROX.

The research presented in this article considers hybrid rocket propulsion using hydrogen peroxide as an oxidizer. Focus is given to high concentrations of this oxidizer. Numerous advantages and disadvantages of hydrogen peroxide as oxidizer, as in the case of all technical solutions, are discussed in [27-29]. The importance of this field of development is due to the fact that such systems cannot be excluded from consideration for various types of space vehicles since new grades of hydrogen peroxide have very high purity and concentration, which makes them feasible for consideration even for long-duration in-space missions. This differs from the case of hydrogen peroxide, available a few decades earlier, which was much less stable.

Current research worldwide considers the use of hydrogen peroxide for propulsive application, using mostly concentrations in the range of $87.5-98 \%$. It is utilized in monopropellant and bipropellant technology developments, and several more niche uses, such as solid propellants and gels, have been also considered. In the case of hybrid propulsion systems, its first applications date back to 1950, where $90 \%$ hydrogen peroxide was tested with polyethylene fuel by the General Electric Company. Over 500 firings took place, and thrust up to approximately $89 \mathrm{kN}$ was demonstrated [30]. More on this propellant combination and the work of General Electric Company is discussed in [31], where advanced concepts, such as throttling, are also mentioned. Later developments between 1960 and 1970 considered work with HTP hybrids using mainly $90 \%$ and $96 \%$ concentrations and are summarized in [32]. Results of several research and development programs using HTP hybrids are presented in [33], where regression rate correlations for HTP with various fuels are collected, and rates exceeding $3 \mathrm{~mm} / \mathrm{s}$ were historically demonstrated for HTP mass fluxes of over $260 \mathrm{~kg} /\left(\mathrm{s} \cdot \mathrm{m}^{2}\right)$ in a classic hybrid configuration (burning of inner surfaces of cylindrical fuel grains with axial oxidizer injection) [34]. This is notable due to historical 
issues concerning low fuel regression rates [3]. Work on HTP hybrid technology was continued in the 1990s [35]. Renewed increased interest in HTP hybrids can be seen in the 21st century and intense experimental research and development has been carried out in the last two decades in over a dozen countries worldwide, including: Australia [36], China [37], France [38], Germany [39], Italy [40], Israel [41], Japan [42], Norway [43], Poland [44], South Korea [45], Taiwan [46], the United Kingdom [47] and the United States [48]. The vacuum performance of a HTP hybrid rocket motor has been demonstrated experimentally with a combustion efficiency of approximately 98\% [49]. Apart from the use of higher HTP grades and concentrations, increased interest in throttleable HTP hybrid rocket motors $[2,50,51]$ and work on solid fuels hypergolic with HTP [41,52] can be seen. Another trend considers additive manufacturing of fuel grains. Recent tests of additively manufactured fuel grains with HTP are discussed in $[44,45,53]$. This includes hot-firing tests of additively manufactured grains with 98\% HTP, where ABS, HDPE and PA6 were tested as fuel [44]. More on additive manufacturing of hybrid fuel grains and their use with various oxidizers can be found in [54].

Across over 70 years of research on HTP hybrid rocket propulsion, the literature mentions the use of hydrogen peroxide with various solid fuels including: HTPB, HDPE, LDPE, ABS, PLA, paraffin, dicyclopentadiene, ammonia borane, CTPB and numerous additives enabling performance or regression rate enhancement. Most commonly, laboratory test campaigns included fuel grains based on HTPB and PE. A survey of studies concerning HTP hybrids is presented in Table 1. Example regression rate data are provided, where the regression is assumed to follow the equation:

$$
\dot{r}=a G_{0 x}{ }^{n},
$$

as given in [28]. $G_{0 x}$ is the oxidizer flow mass flux $\left(\mathrm{kg} /\left(\mathrm{s} \cdot \mathrm{m}^{2}\right)\right), a$ is a constant $(\mathrm{mm} / \mathrm{s})$ and $n$ is the regression rate law exponent [ ]. Each regression rate formula is valid for a given range of oxidizer muss flux, which is discussed in the respective references provided in Table 1. As for motor performance, mainly combustion efficiency has been analyzed. In the case of classic hybrids, low combustion efficiency can occur [55]. This may happen if incomplete mixing is present. However, [32] suggests that high combustion efficiencies occur in the case of HTP hybrids and this is due to the fact that decomposition of hydrogen peroxide involves a significant portion of the total chemical kinetics required for complete combustion of the propellants. Characteristic velocity efficiencies between 85 and $98 \%$ for PE fuel and $88 \%$ HTP as oxidizer have been demonstrated by Wernimont [32]. However, higher $\mathrm{c}^{*}$ efficiency may be expected for higher HTP concentrations and high oxidizer flow mass flux [56]. $\mathrm{c}^{*}$ efficiency exceeding $97 \%$ is possible for non-metalized fuels. [57] provides data of tests of $90 \%$ HTP and PE fuel, where characteristic velocity was between $93.4 \%+/{ }_{-} 1.5 \%$ and $99.6 \%{ }^{+} /{ }_{-} 1.6 \%$ of its theoretical value, where the higher range was obtained for a 14-port grain design and a corresponding increase in the combustion chamber pressure and a decrease in oxidizer-to-fuel ratio. Values of $72-89 \%$ combustion efficiencies for $90 \%$ HTP and highly metalized fuels can be found in [58].

While several in-space and space transportation applications of hybrid rocket propulsion were mentioned in the first paragraph of this paper, HTP hybrid rocket motors in particular are also considered for several uses. This includes space tugs [59], active debris removal systems [60], apogee propulsion [61] and even exploration missions [14]. Unlike the case of $\mathrm{N}_{2} \mathrm{O}$, HTP hybrids are not popular among hobbyist and student projects due to their lower accessibility than $\mathrm{N}_{2} \mathrm{O}$, the oxidizer's strong reactivity (requiring precautions regarding ensuring no contact of HTP with organics) and its poor reputation in some circles due to information in, inter alia, [28,62]. As for space transportation, HTP is gaining wider interest. Two recent suborbital rocket developments using HTP can be outlined: the Polish ILR-33 AMBER and the Norwegian Nucleus. ILR-33 AMBER, developed in-house by the Lukasiewicz Research Network-Institute of Aviation, utilizes $98 \%$ HTP with a $\mathrm{Al}_{2} \mathrm{O}_{3} / \mathrm{Mn}_{\mathrm{x}} \mathrm{O}_{\mathrm{y}}$ catalyst bed and HPDE fuel, and was first flown in 2017 [20,63]. To date, three successful flights of the rocket have taken place and AMBER became the world's 
first vehicle to demonstrate the in-flight use of $98 \%$ HTP. The rocket's most recent version, AMBER 2K, is to enable the launching of small payloads above the Von Karman Line. Nammo's Nucleus utilizes 87.5\% HTP with a silver catalyst bed and HTPB-based fuel and was flown in 2018. Its maiden flight reached an altitude of $107 \mathrm{~km}$ [43]. While these advances stimulated further work on small launch vehicles using hybrid HTP stages [43,64], such concepts were already proposed earlier [65-68] and thrust ranges tested in the United States in around 1950 also considered the use of HTP hybrids in large vehicles. As for nowadays, the Australian company Gilmour Space Technologies develops HTP hybrids [36] with thrust up to $91 \mathrm{kN}$-demonstrated during a single port motor firing in early 2021 [69]. Several other new-space companies are also looking into the potential of using HTP hybrid propulsion for either orbital or suborbital space transportation $[47,70,71]$.

Table 1. Summary of literature review of hybrid propulsion research using HTP as oxidizer.

\begin{tabular}{|c|c|c|c|c|c|c|c|}
\hline $\begin{array}{l}\mathrm{H}_{2} \mathrm{O}_{2} \text { Con- } \\
\text { centration }\end{array}$ & Fuel & $\begin{array}{c}\text { Motor } \\
\text { Thrust }^{1}\end{array}$ & $\begin{array}{l}\text { Ignition } \\
\text { System }\end{array}$ & $\begin{array}{l}\text { Grain } \\
\text { Geometry }\end{array}$ & $\begin{array}{l}\text { Regression Rate Law } \\
\text { Following Equation (1) }\end{array}$ & Injection & Reference \\
\hline $70 \%$ & $\mathrm{PE}$ & & torch & single port & & & [42] \\
\hline $84 \%$ & $\begin{array}{c}\text { Paraffin/C } \\
(95 / 5)\end{array}$ & $385-661 \mathrm{~N}$ & catalytic & single port & $0.0344 \mathrm{G}_{\mathrm{ox}} 0.9593$ & & [72] \\
\hline $70-85 \%$ & ABS & & arc ignition & & & & [73] \\
\hline $80-85 \%$ & $\begin{array}{l}\text { LDPE, HDPE, } \\
\text { polymethyl } \\
\text { methacrylate }\end{array}$ & & $\begin{array}{c}\text { catalytic } \\
\text { (consumable } \\
\text { bed) }\end{array}$ & single port & $\begin{array}{c}0.040 \mathrm{G}_{\text {ox }} 0.78 \\
\text { determined for LDPE } \\
\text { for } \mathrm{G}_{\mathrm{ox}} \text { in the range of } \\
70-211 \mathrm{~kg} /\left(\mathrm{s} \cdot \mathrm{m}^{2}\right) \text { at } 6.9 \mathrm{bar} \\
0.035 \mathrm{G}_{\mathrm{ox}} 0.52 \\
\text { determined for LDPE for } \\
\mathrm{G}_{\mathrm{ox}} \text { in the range of } \\
70-211 \mathrm{~kg} /\left(\mathrm{s} \cdot \mathrm{m}^{2}\right) \text { at } \\
13.8 \mathrm{bar} \\
0.041 \mathrm{G}_{\mathrm{ox}} 0.49 \\
\text { determined for LDPE for } \\
\mathrm{G}_{\text {ox }} \text { in the range of } \\
141-492 \mathrm{~kg} /\left(\mathrm{s} \cdot \mathrm{m}^{2}\right) \text { at } \\
27.6 \mathrm{bar}\end{array}$ & & [74] \\
\hline $87.5 \%$ & PE & $\begin{array}{c}300 \mathrm{~N} \\
\text { (vacuum) }\end{array}$ & catalytic & single port & & $\begin{array}{l}\text { catalyst and } \\
\text { swirl injector }\end{array}$ & [49] \\
\hline $87.5 \%$ & $\mathrm{HTPB}+\mathrm{C}$ & $30,000 \mathrm{~N}$ & catalytic & multiport & & & [43] \\
\hline $87.5 \%$ & $\begin{array}{l}\mathrm{HTPB}+\mathrm{Al} \\
(70 / 30)\end{array}$ & $2400 \mathrm{~N}$ & catalytic & $\begin{array}{l}\text { telescope } \\
\text { (rod-and- } \\
\text { tube } \\
\text { geometry) }\end{array}$ & & shower-head & [75] \\
\hline $88 \%$ & $\mathrm{PE}$ & & catalytic & single port & $0.0535 \mathrm{G}_{\mathrm{ox}}{ }^{0.8}$ & & [32] \\
\hline $85-90 \%$ & ABS & $140 \mathrm{~N}$ & $\begin{array}{c}\text { arc-jet ignition } \\
\text { (small catalyst } \\
\text { bed) }\end{array}$ & single port & & & [48] \\
\hline $90 \%$ & PE & $4450 \mathrm{~N}$ & catalytic & $\begin{array}{c}\text { various, } \\
\text { including } \\
\text { telescope } \\
\text { (rod-and- } \\
\text { tube } \\
\text { geometry) }\end{array}$ & $\sim \mathrm{G}_{\mathrm{ox}} 0.45$ & & [31] \\
\hline $90 \%$ & $\mathrm{PE}$ & $250 \mathrm{~N}$ & catalytic & & & & [76] \\
\hline $90 \%$ & $\mathrm{PE}$ & up to $1250 \mathrm{~N}$ & catalytic & single port & & & [50] \\
\hline $90 \%$ & НTPB & & & single port & $0.04019 \mathrm{G}_{\mathrm{ox}}{ }^{0.5623}$ & shower-head & [77] \\
\hline $90 \%$ & $\begin{array}{c}\text { Paraffin + PE } \\
\text { wax + EVA + SA } \\
+C \\
(50 / 20 / 18 / 10 / 2)\end{array}$ & $11,500 \mathrm{~N}$ & catalytic & single port & $0.279 \mathrm{G}_{\mathrm{ox}}{ }^{0.732}$ & & [78] \\
\hline
\end{tabular}


Table 1. Cont.

\begin{tabular}{|c|c|c|c|c|c|c|c|}
\hline $\begin{array}{l}\mathrm{H}_{2} \mathrm{O}_{2} \text { Con- } \\
\text { centration }\end{array}$ & Fuel & $\begin{array}{c}\text { Motor } \\
\text { Thrust }^{1}\end{array}$ & $\begin{array}{l}\text { Ignition } \\
\text { System }\end{array}$ & $\begin{array}{c}\text { Grain } \\
\text { Geometry }\end{array}$ & $\begin{array}{c}\text { Regression Rate Law } \\
\text { Following Equation (1) }\end{array}$ & Injection & Reference \\
\hline $90 \%$ & 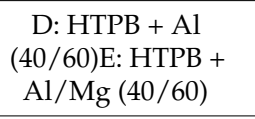 & $90 \mathrm{~N}$ & catalytic & single port & $\begin{array}{l}0.014 \mathrm{G}_{\mathrm{ox}}{ }^{0.7}(\mathrm{D}) \\
0.029 \mathrm{G}_{\mathrm{ox}}{ }^{0.6}(\mathrm{E})\end{array}$ & $\begin{array}{l}\text { porous } \\
\text { injector to } \\
\text { cat bed }\end{array}$ & [58] \\
\hline $90 \%$ & $\begin{array}{l}\text { Dicyclopentadiene, } \\
\text { HTPB with metal } \\
\text { hydrates }\end{array}$ & & catalytic & single port & $\begin{array}{c}0.057 \mathrm{G}_{\mathrm{ox}}^{0.49}(\mathrm{DC}) \\
0.060 \mathrm{G}_{\mathrm{ox}}^{0.50}(\mathrm{HTPB}) \\
0.019 \mathrm{G}_{\mathrm{ox}}^{0.73}(\mathrm{HTPB}+ \\
\left.\mathrm{NaBH}_{4}: 75 / 25\right) \\
0.008 \mathrm{G}_{\mathrm{ox}} 0.90(\mathrm{HTPB}+ \\
\left.\mathrm{NaBH}_{4}: 50 / 50\right) \\
0.037 \mathrm{G}_{\mathrm{ox}} 0.65\left(\mathrm{HTPB}+\mathrm{AlH}_{3}:\right. \\
75 / 25)\end{array}$ & & [79] \\
\hline $90 \%$ & HDPE, PLA, ABS & $250 \mathrm{~N}$ & catalytic & single port & & shower-head & [45] \\
\hline $90 \%$ & LDPE & $4000 \mathrm{~N}$ & catalytic & 4-port & & $\begin{array}{l}\text { full cone } \\
\text { spray }\end{array}$ & [80] \\
\hline $90 \%$ & $\begin{array}{c}\mathrm{LiAlH} 4+\mathrm{PE} \\
(95 / 5)\end{array}$ & & & & & & [34] \\
\hline $90 \%$ & Paraffin & $1000 \mathrm{~N}$ & catalytic & single port & $0.145 \mathrm{G}_{\mathrm{ox}} 0.5$ & & [81] \\
\hline $90 \%$ & $\mathrm{PP}$ & $400 \mathrm{~N}$ & catalytic & single port & & swirl & [82] \\
\hline $91.5 \%$ & HDPE & $300 \mathrm{~N}$ & catalytic & single port & $\begin{array}{c}\text { provided } \\
\text { as function } \\
\text { of swirl number }\end{array}$ & swirl & [82] \\
\hline $90 \%, 95 \%$ & HDPE & $250 \mathrm{~N}$ & catalytic & single port & $\begin{array}{c}0.0320 \mathrm{G}_{\mathrm{ox}}{ }^{0.54}(90 \% \text { HTP }) \\
0.00737 \mathrm{G}_{\mathrm{ox}}{ }^{0.75}(95 \% \text { HTP })\end{array}$ & shower-head & [56] \\
\hline $95 \%$ & $\begin{array}{c}\text { Ammonia } \\
\text { borane, paraffin } \\
\text { wax and } \\
\text { hypergolic } \\
\text { additives }\end{array}$ & & hypergolic & & & & [52] \\
\hline $87.5 \%, 98 \%$ & PE & $250 \mathrm{~N}$ & catalytic & end-burning & $\begin{array}{c}0.0446 \mathrm{G}_{\mathrm{ox}}^{0.3288}(87.5 \% \\
\text { HTP })\end{array}$ & $\begin{array}{l}\text { annular ring } \\
\text { swirl } \\
\text { injection, } \\
\text { with six } \\
\text { catalyst beds }\end{array}$ & [38] \\
\hline $90-98 \%$ & НТРВ & & & & $\begin{array}{l}9.39210^{-2} \mathrm{G}_{\mathrm{ox}}{ }^{0.53} \\
(90 \% \text { HTP }) \\
9.82410^{-2} \mathrm{G}_{\mathrm{ox}} 0.53 \\
(98 \% \text { HTP })\end{array}$ & & [83] \\
\hline $98 \%$ & HDPE & $4000 \mathrm{~N}$ & catalytic & wagon wheel & & shower-head & [20] \\
\hline $98 \%$ & $\begin{array}{c}\text { A: } \mathrm{HTPB}+\mathrm{Al} \\
(80 / 20) \\
\text { B: } \mathrm{HTPB}+ \\
\mathrm{C}_{14} \mathrm{H}_{10}+\mathrm{Al} \\
(60 / 20 / 20) \\
\mathrm{C}: \mathrm{HTPB}+\mathrm{Al}+ \\
\mathrm{Mg}+\mathrm{C} \\
(60 / 28 / 10 / 2)\end{array}$ & $1000 \mathrm{~N}$ & $\begin{array}{l}\text { solid } \\
\text { propellant } \\
\text { igniter }\end{array}$ & single port & $\begin{array}{c}3.938810^{-3} \mathrm{G}_{\mathrm{ox}}{ }^{1.0433} \text { (A) } \\
4.293810^{-3} \mathrm{G}_{\mathrm{ox}}{ }^{1.0336} \text { (B) } \\
2.667610^{-2} \mathrm{G}_{\mathrm{ox}}{ }^{0.72493} \text { (C) }\end{array}$ & shower-head & {$[84,85]$} \\
\hline $98 \%$ & НТРВ & $100 \mathrm{~N}$ & catalytic & single port & & shower-head & {$[86,87]$} \\
\hline $98 \%$ & PE & & $\begin{array}{l}\text { no catalytic } \\
\text { bed }\end{array}$ & single port & & annular gap & [51] \\
\hline $98 \%$ & ABS, HDPE, PA6 & $200 \mathrm{~N}$ & catalytic & wagon wheel & & shower-head & [44] \\
\hline
\end{tabular}

${ }^{1}$ Thrust levels differ between tests and are provided only for rough order of magnitude reference.

Theoretical performance calculations of HTP hybrid rocket motors using PE as fuel can be seen in Figure 1. Computations were done using NASA CEA [88] with Matlab in-house code utilized for results visualization, while the MatlabCEA tool [89] was used to connect Matlab with NASA CEA. A motor chamber pressure of 20 bar and a 20:1 nozzle expansion ratio were set assuming flow frozen at chamber. Data for various HTP concentrations are 
presented. The $98 \%$ HTP grade allows for reaching a $4.5 \%$ higher specific impulse than in the case of the $87.5 \%$ grade, which is popular in Europe. Additional system-level gain is available due to the increased density of $98 \%$ HTP $\left(1431.0 \mathrm{~kg} / \mathrm{m}^{3} \mathrm{vs} .1373 .3 \mathrm{~kg} / \mathrm{m}^{3}\right.$ at $25^{\circ} \mathrm{C}$ ). Higher HTP concentrations have lower optimal oxidizer-to-fuel ratios but lead to an increase in volumetric performance. Use of $98 \%$ HTP provides a $3.5 \%$ increase in specific impulse in comparison to motors using $\mathrm{N}_{2} \mathrm{O}$ as oxidizer and the gain in terms of density-specific impulse is 70\% [2]. Moreover, the high oxidizer-to-fuel ratio of HTP hybrids allows for efficient vehicle sizing and launch mass minimization. While work with hybrid rocket motors using 98\% HTP has not been described in the literature until the 21 st century, tests of $98 \%$ HTP within catalyst beds were mentioned in the literature in the early 1960s [90].

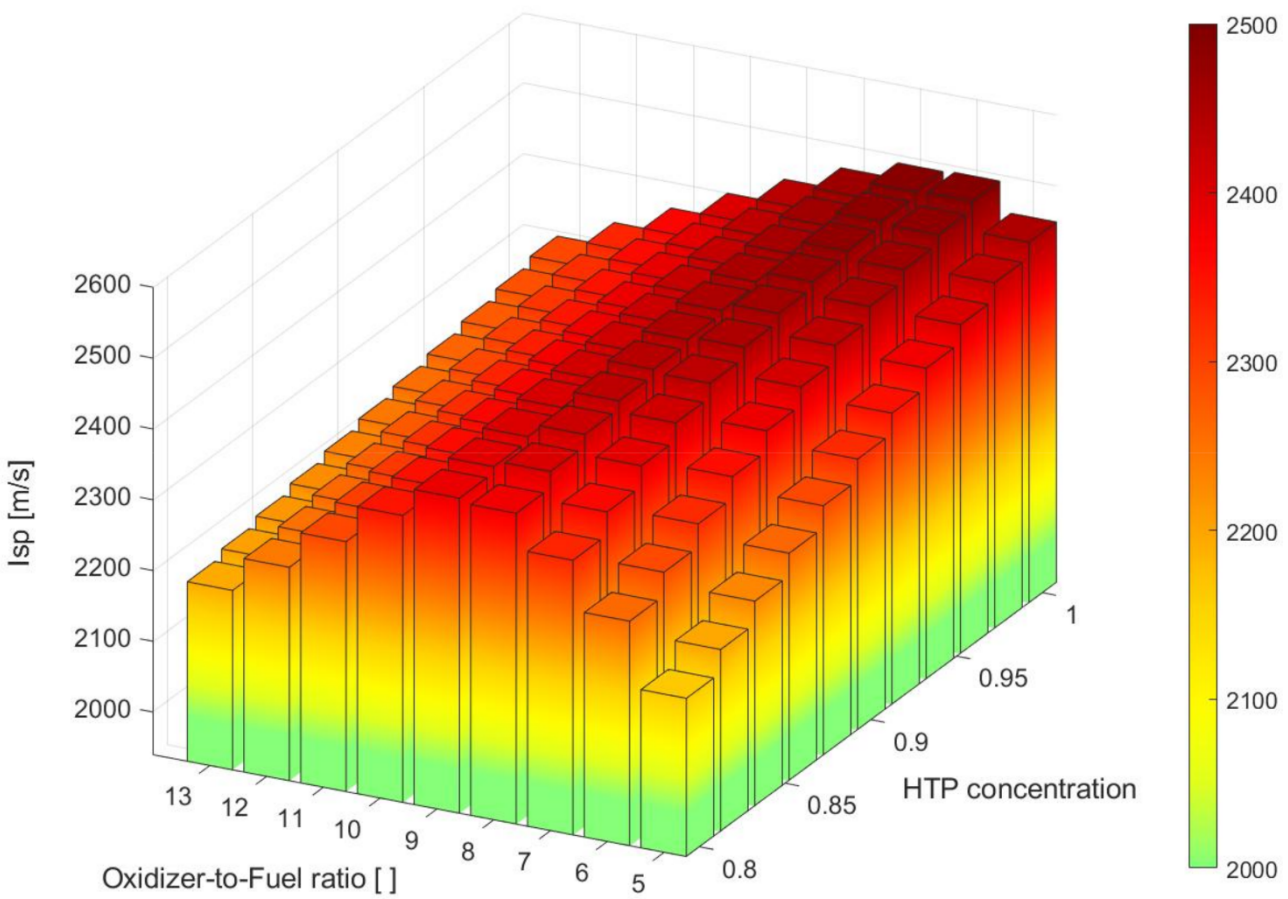

Figure 1. Theoretical performance of $98 \%$ HTP hybrid propulsion using PE as fuel.

One essential property of propellants considered for in-space application is storability. Several promising results have been obtained for high HTP concentrations. Qualification of a storage and transportation container, made of HDPE, for propellant-grade hydrogen peroxide, was performed in Poland in 2017. Approximately 98-99\% (by mass-concentrations varied due to originating from several manufacturing processes) HTP was stored in vented 5 liter PE containers located in a dark storage room for 6 months at $22^{\circ} \mathrm{C}$, at atmospheric pressure, with no evidence of concentration loss. Part of this propellant was transported to the Institute of Aviation, where it is still being stored in a refrigerated storage room in PE containers, at $10{ }^{\circ} \mathrm{C}\left({ }^{+} /-2{ }^{\circ} \mathrm{C}\right)$. The propellant concentration after 4 years of storage dropped to approximately $97.8 \%$ (by mass). Operational and ground long-term storability have been demonstrated in the United States in the past. Syncom II, Syncom III and Early Bird spacecraft used hydrogen peroxide monopropellant propulsion systems. The useful life of Early Bird was estimated at 5 years. A ground storage experiment performed by FMC Corporation confirmed that $90 \%$ hydrogen peroxide, stored for 17 years at $5{ }^{\circ} \mathrm{C}$, essentially did not decompose [27]. More examples of promising HTP storability data and its comparison to hydrazine storability can be found in [91]. A comparison of the storage of $90 \%$ and $98 \%$ HTP is available in [92], which dates back to 1961 . However, since that time, advances in HTP manufacturing technology and purity have been made, which influence 
its long-term storability. It is considered that $98 \%$ HTP and even higher-concentration technology may be a promising alternative for classic storable oxidizers used within today's satellite platforms [91]. While, two decades ago, the use of 98\% HTP in propulsion was still considered to be associated with development risks in comparison to the use of $90 \%$ HTP, $[93,94]$ describe it as being much safer than storable oxides of nitrogen. The higher the concentration of HTP, the better storability and stability occur [27]. [27] shows that for a given concentration of HTP, its stability increased in the last few decades due to optimized manufacturing technologies and thus improved purity.

While key research in the field of HTP hybrids has been herein presented, focus shall be given to $98 \%$ HTP technology. The main aim of this work is to discuss the key steps taken to develop $98 \%$ hybrid rocket technology and present its performance, including data obtained during extensive ground and in-flight testing during the last decade. The significance of this paper is due to limited data regarding high-TRL hybrid systems using such high HTP concentrations.

\section{Technology Development Initiation-The First Steps}

Modern chemical rocket propulsion developments for space applications started in Poland, with feasibility studies led by Wolanski since 2005 . They concerned potential liquid rocket propulsion developments [95]. However, the first mention of hybrid rocket propulsion was noted significantly earlier-in 1965, when Wolanski introduced the concept to the Polish aerospace community [96]. The first experimental concept verification of hybrid rocket propulsion was achieved via the cooperation of the Institute of Aviation and Warsaw University of Technology in 2007 and used gaseous oxygen as an oxidizer [97]. A metalized fuel was used and its grain included the addition of solid oxidizer particles to increase the grain regression rate. Further attention was given to using hydrogen peroxide as an oxidizer, and concepts of satellite propulsion systems were proposed [98]. Propellant-grade hydrogen peroxide was desired. However, it was unavailable in Poland at that time. High costs and complex procedures applied for import, e.g., from Germany. Experimental work in this field started at the Institute of Aviation in 2011, from obtaining samples of propellant-grade hydrogen peroxide. Here, $98 \%$ peroxide was obtained in situ by vacuum fractional distillation of commercially available $60 \%$ solution and purified with a vacuum rotary evaporator. Later, the two-stage method of preparation of $98 \%$ ultra-pure HP evolved to a single-stage technology, eventually patented in 2018. The HTP manufacturing technology is currently secured by patents in over 20 countries around the world.

The first lab-scale, $100 \mathrm{~N}$ class, hybrid rocket motor was successfully fired in 2012. All hardware, including the feed system and the motor, were assembled at the Institute of Aviation. The decomposition catalyst was based on stainless steel-alumina wire mesh-supported platinum, packed in a $200 \mathrm{~mm}$ pile. The catalyst bed applied for further experiments was modified by means of length reduction and replacement of the catalyst with alumina-supported manganese oxides. The results of the first tests, performed with in-house made catalysts, are presented in Figure 2, and further data are available in [87]. These tests utilized a single circular port grain. Single firings (see Figure 2a-d) [87] were performed using a catalyst bed of $50 \mathrm{~mm}$ in length with different HTP feeding pressures (12 bar and 14 bar, respectively). Pulse-mode operation (see Figure 2e) was also successfully demonstrated. Catalyst preheating allowed for minimization of the time needed for reaching the nominal thrust level, and the monopropellant phase was eliminated (below $0.1 \mathrm{~s}$ was needed to obtain maximum thrust). 


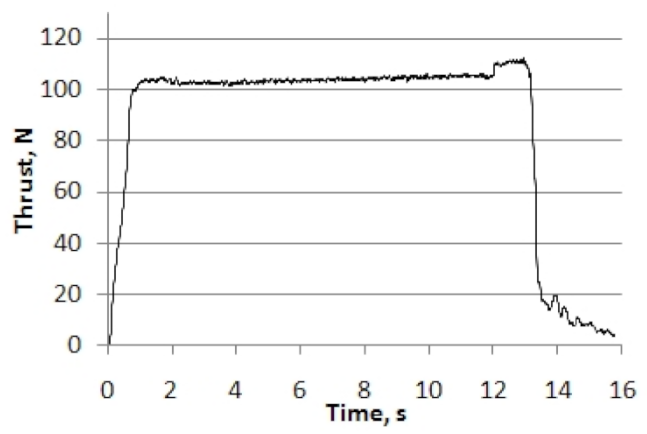

(a)

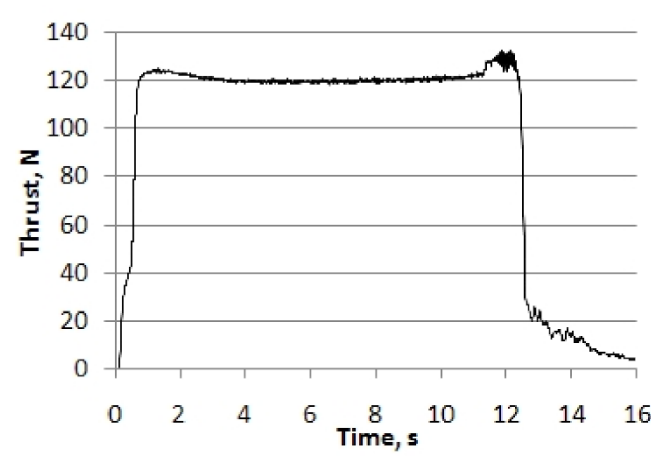

(c)

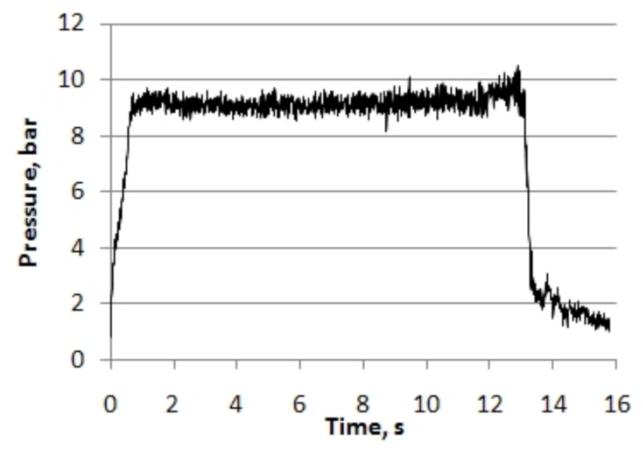

(b)

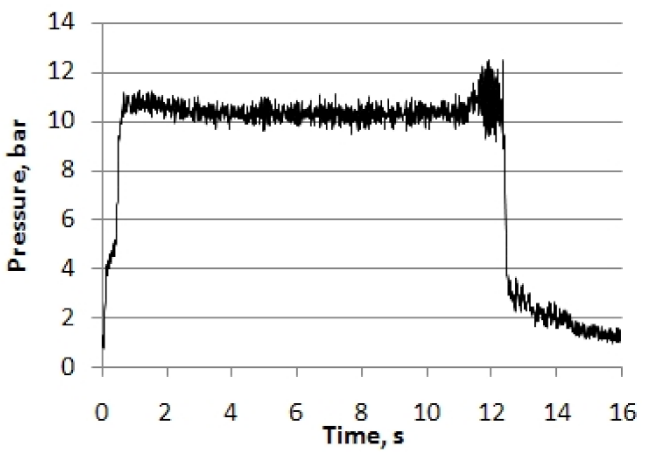

(d)

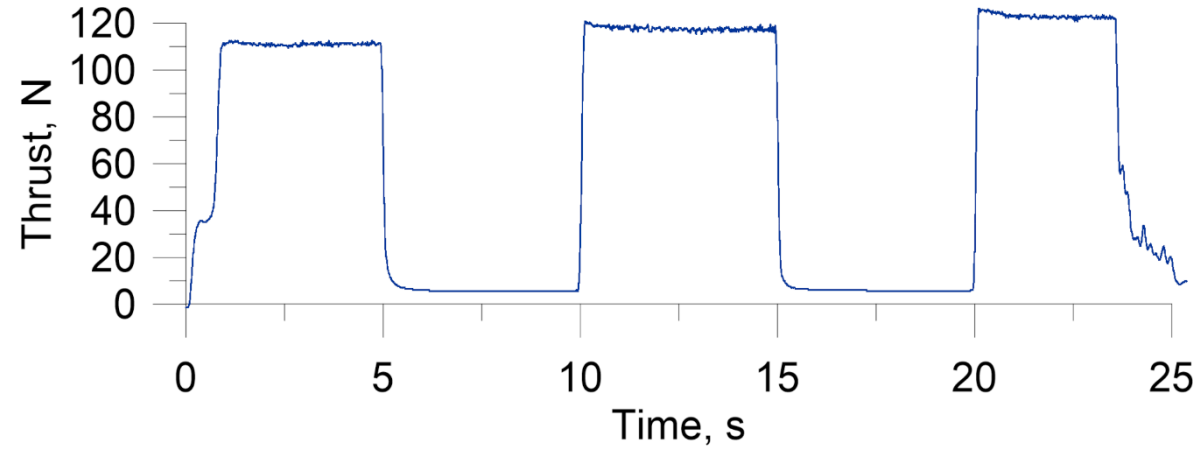

(e)

Figure 2. Selected results of hot fire tests of hybrids using $98 \%$ HTP and HTPB as propellants conducted at IoA during 2012-2013 [87,99]: (a,b) thrust and chamber pressure profile of the single hot fire test no. $1 ;(\mathbf{c}, \mathbf{d})$ thrust and chamber pressure profile of the single hot fire test no. 2; (e) thrust profile of $5 \mathrm{~s}$ on $/ 5 \mathrm{~s}$ off pulse mode operation.

Small-scale testing led to validation of hybrid motor performance modeling. Experience was also gained with handling high concentrations of hydrogen peroxide, also due to the finalization of the first international projects connected to using hydrogen peroxide in various chemical propulsion systems. The demonstrated reliability of hybrid rocket motor ignition, firing stability and the Institute's increased focus on space technology led to further development plans [100]. The decision to develop a small suborbital rocket was made. Experience from internal R\&D actions and projects conducted within the programs of the European Space Agency and European Commission was to be used. Moreover, team expansion was planned, based mainly on the swift transition of technical university graduates to young professionals - this included using the outcome of the educational Polish Small Sounding Rocket Program run at Warsaw University of Technology [101,102]. The new rocket was to be fully developed at the Institute of Aviation and had the goal of demonstrating capabilities in the field of space transportation and advanced chemical 
rocket propulsion. As discussed in [103], the propulsion system trade-off led to the selection of hybrid rocket technology based on $98 \%$ hydrogen peroxide. The alternative was a green bipropellant system due to this technology being developed in parallel projects at the Institute of Aviation [104-106]. The vehicle was sized in order to allow the launch of small suborbital payloads to the Von Karman Line. Efforts dedicated to defining the configuration of the new hybrid rocket vehicle took place in late 2014, and in 2015, hardware developments were initiated. It was decided to use two solid rocket motor boosters along the main hybrid stage, which allowed vehicle mass minimization and overall mission thrust-curve optimization [2]. The rocket was named ILR-33 AMBER and was to present the world's first in-flight use of $98 \%$ hydrogen peroxide.

\section{Materials and Methods Relevant to Hybrid Rocket Motor Hot Fire Testing}

While extensive test data were available from subscale hybrid rocket motor test campaigns $[86,87,99]$, the new vehicle required a dedicated propellant trade-off taking into account performance, regression rate, grain manufacturing and potential scalability. Performance modeling was done using codes by Surmacz (subscale motor evaluation), Bartkowiak (flight motor design), Okninski and Matyszewski (sizing and optimization). Data acquisition was done using the in-house rocket propulsion test facility infrastructure. A PXI setup with in-house LabVIEW software by Sobczak and Mayer was used.

\subsection{Development Steps and Relevant Methods}

Since this article is focused on presenting an overview of nearly 10 years of development of hybrid rocket propulsion using $98 \%$ HTP, in-depth focus on methods is not presented. However, several references to applicable sources are given in Table 2.

Table 2. Key methods-propulsion technology development for the ILR-33 AMBER rocket.

\begin{tabular}{|c|c|c|}
\hline Development Task & Approach & Outcome \\
\hline fuel candidates down-selection & $\begin{array}{c}\text { literature review, use of data of previous } \\
\text { in-house test }[86,87,99]\end{array}$ & $\begin{array}{l}\text { high-density polyethylene (2 variants, } \\
\text { paraffin, polyamide (PA6) }\end{array}$ \\
\hline $\begin{array}{l}\text { fuel regression } \\
\text { rate determination }\end{array}$ & $\begin{array}{c}\text { subscale firings of laboratory hybrid } \\
\text { rocket motors } \\
\text { using } 98 \% \text { HTP } \\
\text { and down-selected fuels (Figure 3) }\end{array}$ & $\begin{array}{l}\text { regression rate formulas for each } \\
\text { propellant combination }\end{array}$ \\
\hline $\begin{array}{l}\text { catalyst development for } 98 \% \text { HTP for } \\
\text { burn durations exceeding } 40 \mathrm{~s} \text { and mass } \\
\text { flow rates up to } 1.5 \mathrm{~kg} / \mathrm{s}\end{array}$ & use of earlier verified catalyst technology & $\begin{array}{l}\text { use of a catalyst bed using } \mathrm{Al}_{2} \mathrm{O}_{3} \text { support } \\
\text { and } \mathrm{Mn}_{\mathrm{x}} \mathrm{O}_{\mathrm{y}} \text { active phase }[86,107,108]\end{array}$ \\
\hline $\begin{array}{c}\text { thermal insulation and low-regression } \\
\text { ablative insert degradation } \\
\text { characterization }\end{array}$ & $\begin{array}{c}\text { subscale firings of laboratory motors and } \\
\text { engines }\end{array}$ & $\begin{array}{l}\text { regression rates of materials in various } \\
\text { critical locations within the combustion } \\
\text { chamber and nozzle assembly }\end{array}$ \\
\hline $\begin{array}{l}\text { feeding system operation and } \\
\text { performance validation }\end{array}$ & $\begin{array}{c}\text { ground-testing dynamic characteristics of } \\
\text { pressure regulator, valves and } \\
\text { measurement devices via feeding water } \\
\text { using the helium pressurant }\end{array}$ & $\begin{array}{c}\text { datasets of temperature and pressure in } \\
\text { feeding system, particularly with focus } \\
\text { on conditions in helium tank and } \\
\text { oxidizer tank [20] }\end{array}$ \\
\hline $\begin{array}{l}\text { pre-flight motor operation and } \\
\text { performance validation }\end{array}$ & $\begin{array}{l}\text { ground firings of full-scale hybrid rocket } \\
\text { motors }\end{array}$ & $\begin{array}{l}\text { datasets of pressures, temperatures, mass } \\
\text { flows along test-site feeding system and } \\
\text { within the motor itself, thrust } \\
\text { measurement and extensive data from } \\
\text { vision systems (including fast cameras } \\
\text { and thermovision) [20] }\end{array}$ \\
\hline $\begin{array}{c}\text { in-flight hybrid rocket motor technology } \\
\text { verification }\end{array}$ & suborbital launch of rocket demonstrator & $\begin{array}{c}\text { in-flight data of hybrid rocket motor } \\
\text { operation }{ }^{1}[20,63,109]\end{array}$ \\
\hline
\end{tabular}

${ }^{1}$ First flights were conducted to limited apogee due to launch site restrictions. 


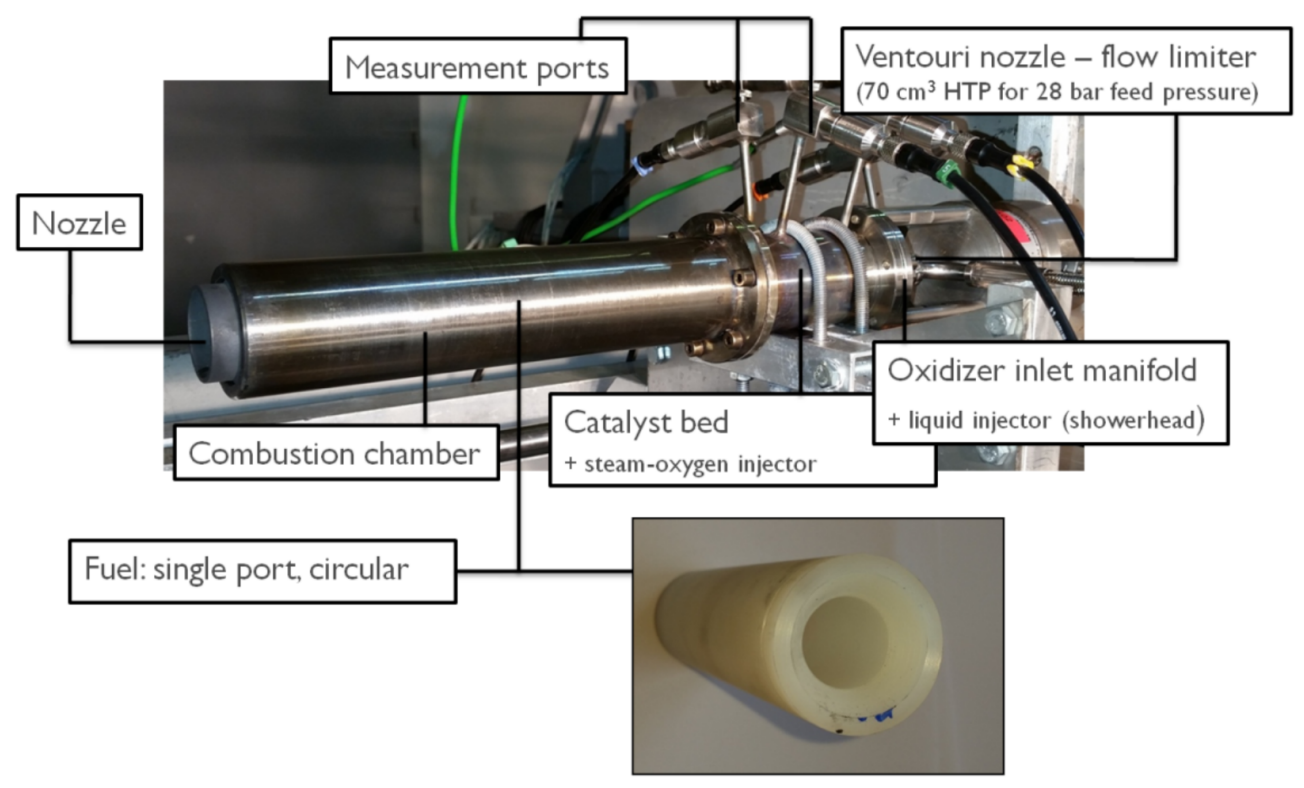

Figure 3. Laboratory hybrid rocket motor for fuel regression characterization, circa $100 \mathrm{~N}$ of thrust.

The test laboratory motor for hybrid fuel evaluation before the final trade-off concerning the fuel to be used by the ILR-33 AMBER is presented in Figure 3.

\subsection{Overview of the Flight Hybrid Rocket Motor of the ILR-33 AMBER}

The hybrid propulsion system utilizes a helium pressure-fed system. The oxidizer is held in an aluminum alloy-welded tank. The tank, as well as the main flow valve and most of the flow components, were developed in-house. The propellant tank and hybrid motor combustion chamber have an outer diameter of approximately $230 \mathrm{~mm}$, thus also serving as the vehicle's airframe. The hybrid rocket motor provides approximately $150 \mathrm{kNs}$ of total impulse at sea level at its full burn duration. It uses a carbon fiber-reinforced plastic (CFRP) casing and a phenolic-based thermal insulation. Its nozzle utilizes a composite low-erosion throat insert. The HDPE grain has 8 ports in a wagon wheel configuration, ensuring a near-to-constant thrust level during the circa $40 \mathrm{~s}$ burn. While the first version of the motor (Mk2017) had an average sea-level thrust of $3800 \mathrm{~N}$, further motor modifications aimed at increasing its performance. This was done inter alia via improvement of the ablative insert technology and limiting its erosion. First changes of the motor design considered optimization of the internal insulation and acceptable thermal loads. Thermovision was used during each firing to study which parts of the motor needed improvements and which ones may have overly high safety factors regarding thermal loads and the maximum operating temperature. The CFRP casing was a key part of the design, since its maximum temperature is limited by the glass transition temperature of the resin system used. While the HDPE fuel grain geometry restricts the access of combustion products to the thermal insultation along its length, the region between the catalyst bed and the fuel grain, as well as the region in proximity to the post-combustion chamber, were crucial in terms of heat reaching the CFRP motor casing. While many hybrid rocket motors using HTP as oxidizer utilize a catalyst bed mounted on top of the combustion chamber, the design of the motor by Bartkowiak incorporated a catalyst bed submerged into the CFRP casing. Further modifications allowed motor mass minimization and its elongation was slightly increased in order to increase the overall delivered total impulse. Most recent changes included modification of fin attachment points to the motor's structure.

\subsection{Overview of the ILR-33 AMBER Suborbital Rocket}

The ILR-33 AMBER is small suborbital rocket using a hybrid main stage. Two solid rocket boosters used along the hybrid stage burn only during the first few seconds of 
flight and are discarded after their burnout [110]. Figure 4 presents the ILR-33 AMBER flight configuration (a) and the planned AMBER 2K (b). The two vehicles are compared in Table 3.

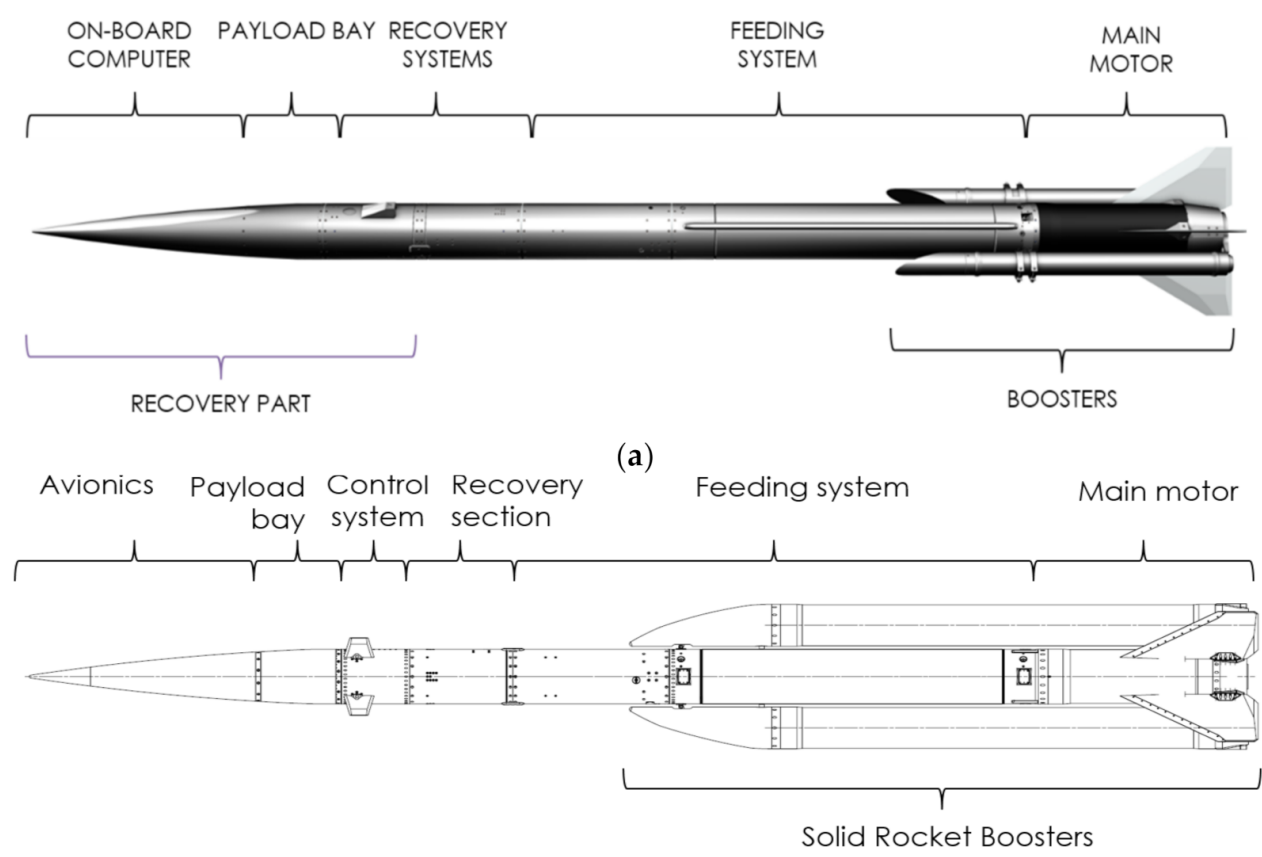

(b)

Figure 4. The ILR-33 AMBER in (a) its first version and (b) the ILR-33 AMBER 2K configuration [109].

Table 3. Key methods-propulsion technology development for the ILR-33 AMBER rocket.

\begin{tabular}{ccc}
\hline Parameter & ILR-33 AMBER & ILR-33 AMBER 2K \\
\hline Launch mass & $160 \mathrm{~kg}$ & $270 \mathrm{~kg}$ \\
\hline Nominal payload mass & $5 \mathrm{~kg}$ & $10 \mathrm{~kg}$ \\
\hline $\begin{array}{c}\text { Hybrid rocket motor main core total impulse } \\
\text { (sea level) }\end{array}$ & $150 \mathrm{kNs}$ & $156 \mathrm{kNs}$ \\
\hline Hybrid rocket motor main core burn duration & $40 \mathrm{~s}$ & $39 \mathrm{~s}$ \\
\hline $\begin{array}{c}\text { Solid rocket motor booster stage total impulse } \\
\text { (sea level) }\end{array}$ & $27 \mathrm{kNs}$ & $176.8 \mathrm{kNs}$ \\
\hline Solid rocket motor booster stage burn duration & $2.6 \mathrm{~s}$ & $6.1 \mathrm{~s}$ \\
\hline
\end{tabular}

\section{Results}

\subsection{Subscale Testing of Fuels for Use with 98\% Hydrogen Peroxide}

Subscale testing allowed for the evaluation of fuels-performance and burn rate characteristics were obtained. Figure 5 shows an image from one of the motor firings. Figure 6 presents the operating parameters of the subscale motor gathered from four separate firings with HDPE fuel.

The following regression law was obtained for HDPE and has been used for designing the hybrid rocket motor for the ILR-33 AMBER rocket:

$$
\dot{r}=0.04291 G_{o x}^{0.529}
$$

It has to be noted that for the flight motor of the vehicle, where the nominal thrust level is circa 20-fold higher than in the subscale motor, lower regression rates were measured. 
This is in-line with theory-scaling effects regarding grain regression rates are discussed in [77].

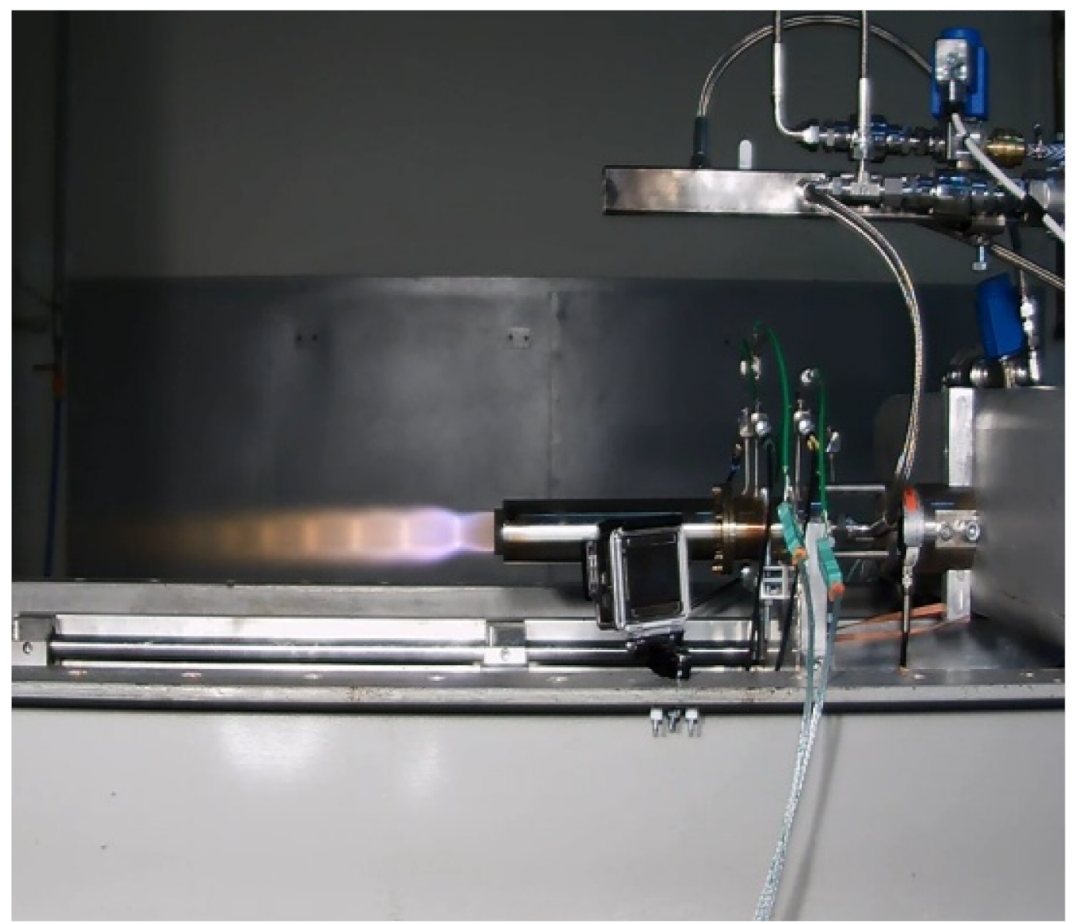

Figure 5. Hot-firing of laboratory hybrid rocket motor, which was used for regression rate characterization of several solid fuels with $98 \%$ HTP before propellant trade-off finalization for the core hybrid stage of the ILR-33 AMBER suborbital rocket.

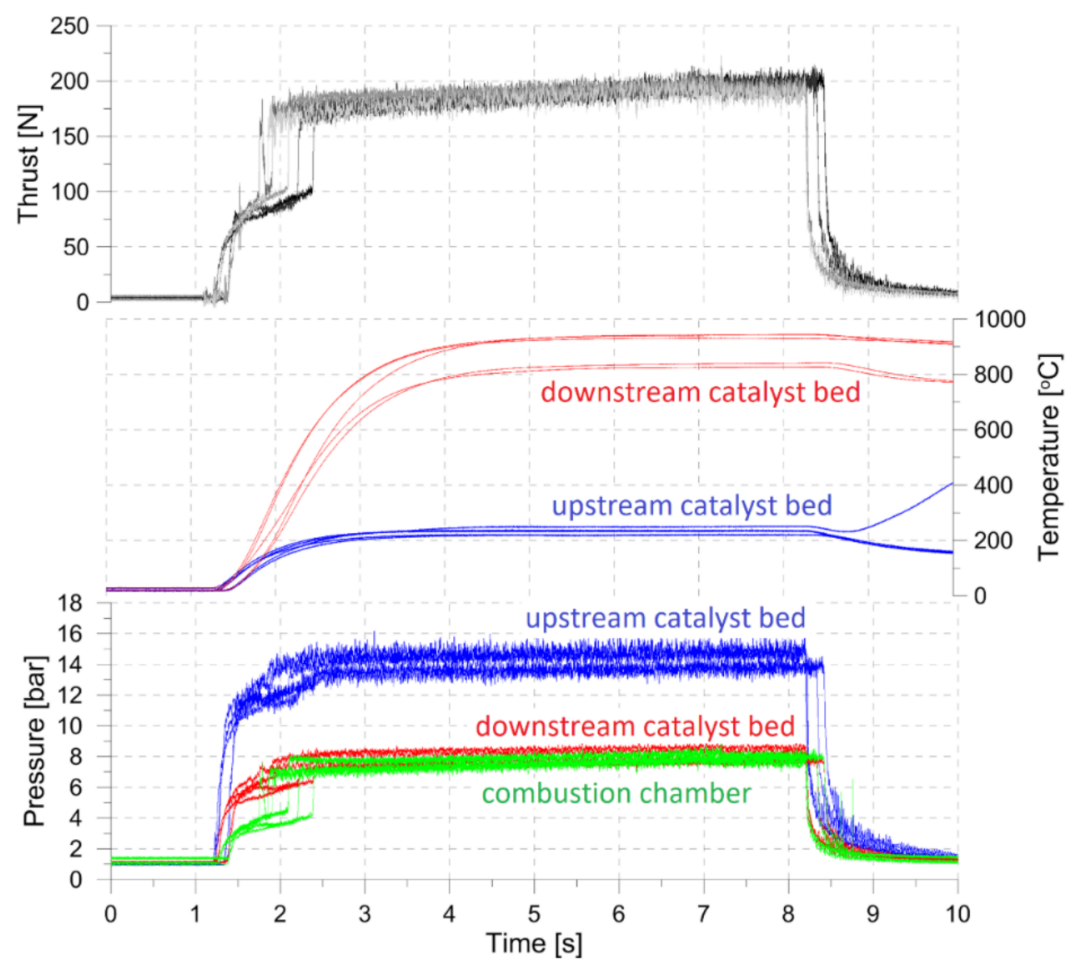

Figure 6. Operating parameters of a subscale hybrid rocket motor (tests of 98\% HTP with HDPE)results of four subsequent hot fire tests. 


\subsection{Full-Scale Testing of the ILR-33 AMBER Hybrid Propulsion System}

Full-scale hybrid rocket motor tests were conducted on several development models. Figure 7 presents one of the firings, where the Mk2018 motor was used. Since 2017, several advances have been made both in terms of modeling as well as regarding motor design features. The Mk2020 motor is the most advanced version, using a minimum erosion nozzle insert, thus maximizing the delivered performance. Its predecessor, the Mk2019+, is a lower-performance motor due to the use of a graphite throat insert, which shows erosion. Results of Mk2019+ firings are shown in Figure 8. Data presented include characteristic velocity and specific impulse values during a full burn duration firing. Their uncertainty is marked in Figure 8. Thrust, chamber pressure and oxidizer mass flow uncertainties were taken from manuals of the measurement instruments used. A $2 \%$ uncertainty of determination of the nozzle throat area was assumed a priori, while its linear erosion rate is considered to be constant in time and was calculated using the initial and post-firing nozzle diameters. Figure 9 shows the start-up phase of the Mk2019+ motor. The transition from monopropellant to hybrid mode is visible.

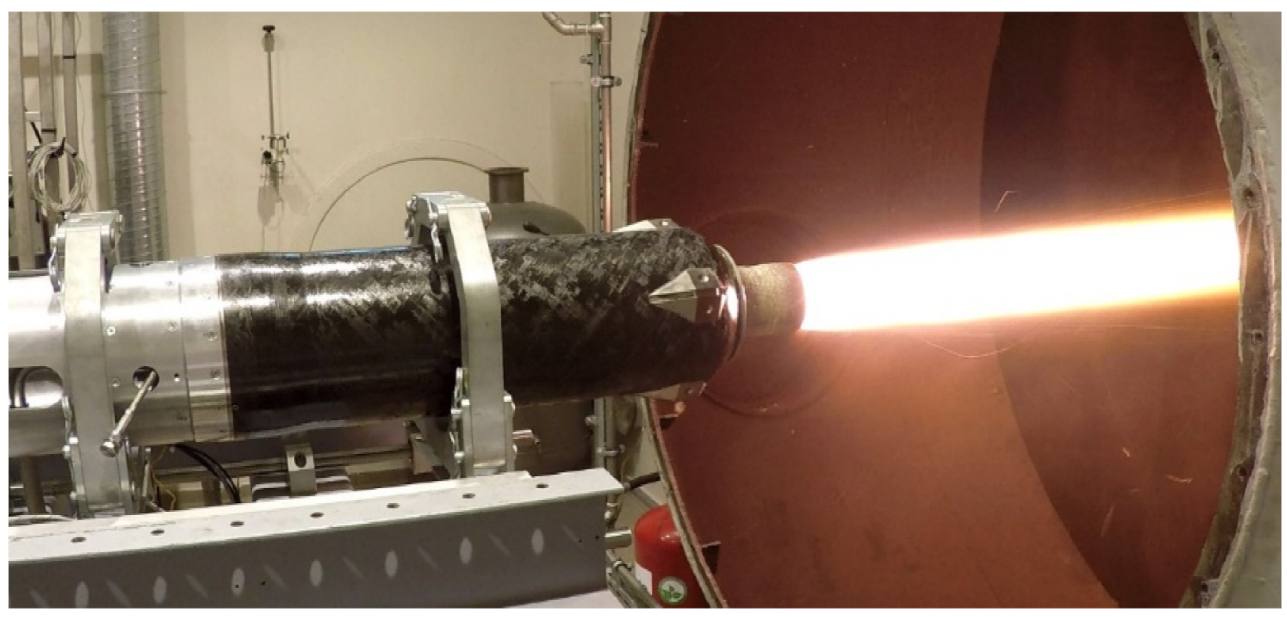

Figure 7. Sea level hot-firing of the full-scale hybrid rocket motor (Mk2018) of the ILR-33 AMBER rocket, using 98\% HTP as oxidizer and HDPE as fuel.

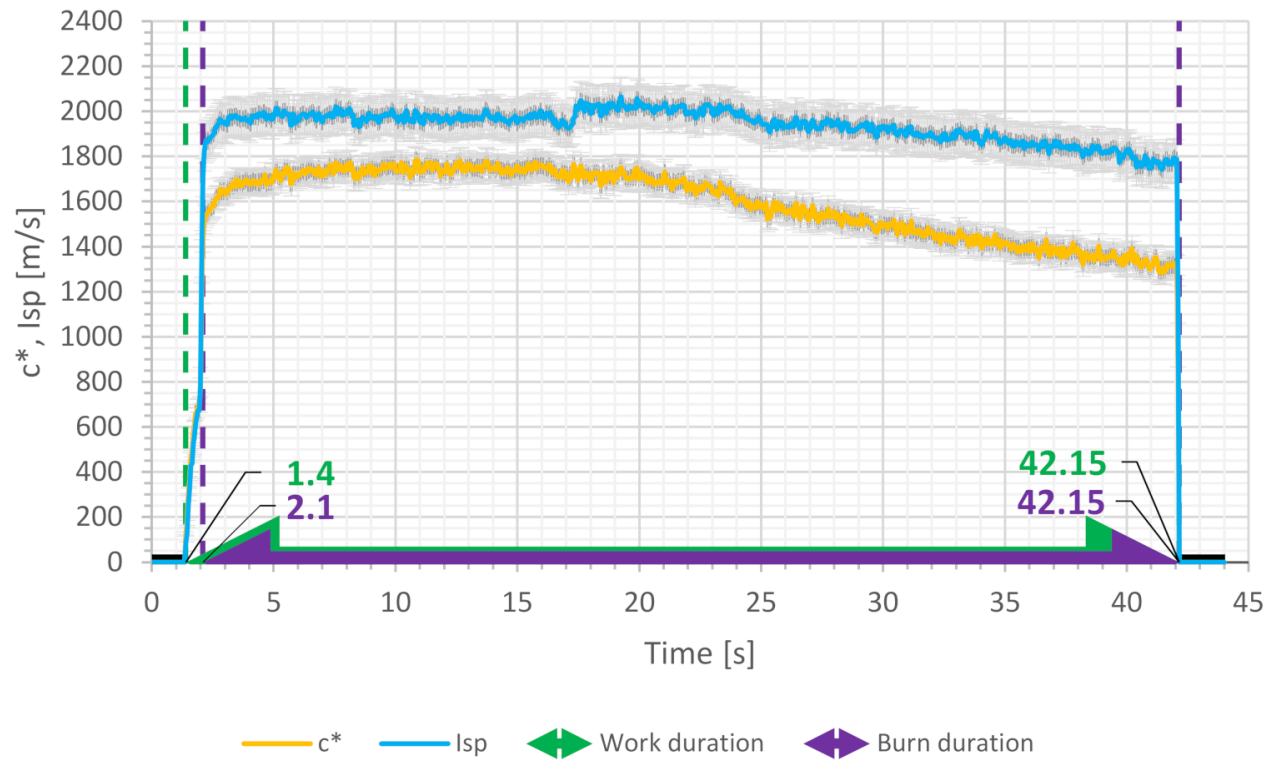

Figure 8. Results of test-bench hot-firing of the Mk2019+ hybrid rocket motor: the characteristic velocity and specific impulse obtained are shown, including their determination uncertainties. 


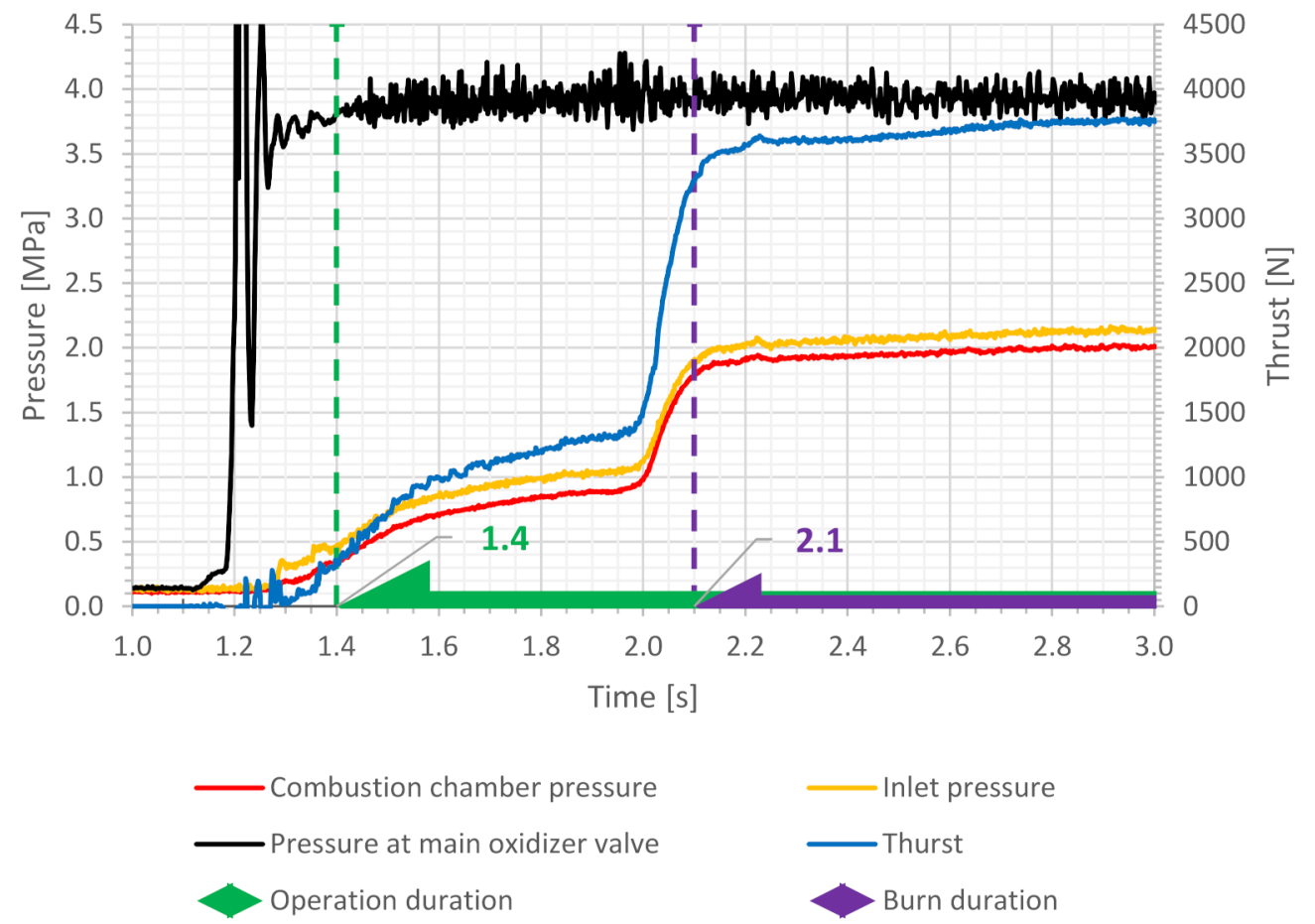

Figure 9. Start-up phase of the Mk2019+ hybrid rocket motor during ground testing.

The 2017 maiden flight of the ILR-33 AMBER used the Mk2017 motor and the 2019 flight utilized the Mk2019 configuration. The Mk2019+ was only tested on-ground in order to demonstrate the full burn duration of the hybrid propulsion system.

\subsection{In-Flight Test Campaigns}

In-flight testing was conducted at Polish military test ranges. During the first three launches of the ILR-33 AMBER rocket during 2017-2019, the following altitudes were obtained: $15 \mathrm{~km}, 10.5 \mathrm{~km}$ and $23 \mathrm{~km}$. While the vehicle's configuration allowed fewfold higher performance even at these stages of development [2,103], the altitude was limited by only partial filling of the oxidizer tank with hydrogen peroxide. The test range size and atmospheric conditions (wind conditions before each launch were determined using balloon sounding [111] and influenced the final rocket launch tower's elevation and oxidizer mass) did not allow higher apogees to be reached at the time of test site availability. During the maiden flight of the rocket, 28 liters of HTP were loaded; during the second one, 19 liters were loaded, and during the last one, 32.8 liters were loaded. It is, however, notable that the vehicle's structure and subsystems varied between these flights (due to several mechanical iterations in order to test components at various development stages, not only propulsion). Maximum tank loading (approximately 52 liters in the vehicle tested in the third flight) would allow $60 \mathrm{~km}$ of altitude to be reached using the ILR-33 AMBER vehicle. Altitudes of up to $100 \mathrm{~km}$ would be possible after further improvement of the dry mass fraction [2,103], but this would require significant development effort, and new requirements considering potential payloads anyhow led to a new vehicle, the ILR-33 AMBER 2K; thus, final optimization of the first version of AMBER was not undertaken. The new version (AMBER $2 \mathrm{~K}$ ) shall use larger solid rocket booters and a hybrid rocket motor with a $4 \%$ increase in its total impulse (Table 3). As for further vehicle testing, initial flights of the ILR-33 AMBER 2K will take place in Poland. However, the limited size of Polish test ranges leads to the need for international cooperation regarding test ranges for further flights. Alternatively, reliable control systems could enable safe flights on national sites, which is analyzed in [112]. 
A comparison of the flight performance of the Mk2017 hybrid rocket motor with its initial performance simulation and data from its first ground firing was done. A different burn duration was used during flight via different oxidizer mass loading. Apart from this, the in-flight performance was close to that measured on the ground-while the first post-flight estimations can be seen in Figure 10 (when simplifications regarding base drag estimation were used), further analyses of data showed that in-flight performance was $1 \%$ above test-bench data in terms of thrust (recalculated to sea-level performance, but omitting the $2.6 \mathrm{~s}$ duration of booster stage burn, when less precise data are present due to high vibrations of the whole vehicle and higher acceleration measurement dispersions). Some difference in thrust can be seen around $10.5 \mathrm{~s}-$ it is, however, due to some inaccuracy regarding determination of the aerodynamic coefficients at Mach 1, which were used for recalculating the thrust curve from flight. This shall be discussed further in a dedicated paper. It can be seen that during the maiden flight of the ILR-33 AMBER rocket, booster separation occurred approximately $15 \mathrm{~s}$ after the end of burn. This was due to non-nominal performance-aerodynamic loads were used to ensure immediate separation of the booster stage at their burnout, as discussed in [103,113]. Further flights included booster separation systems using pyrotechnical devices apart from aerodynamic loads, which was found to be successful.

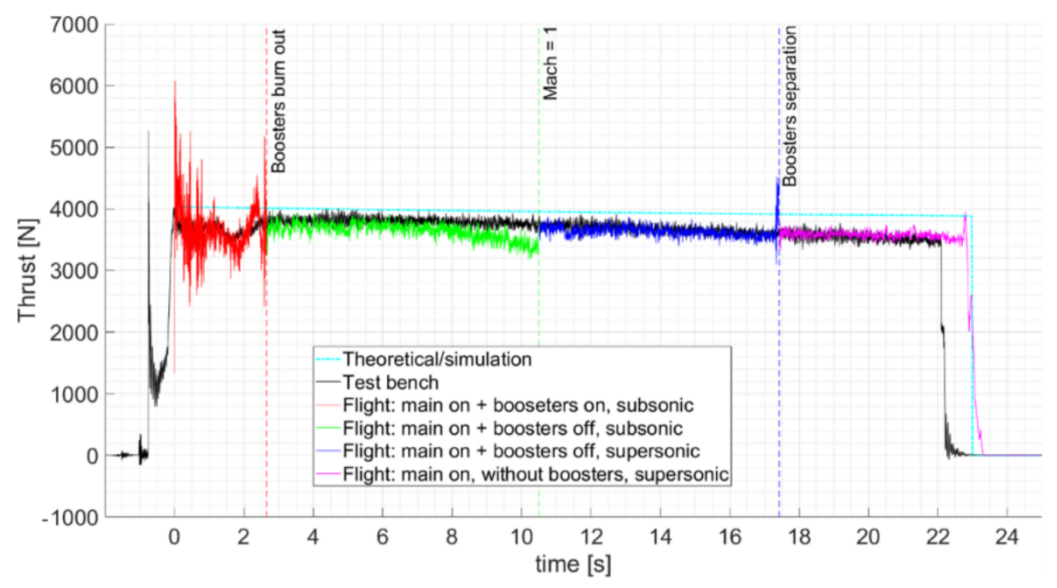

Figure 10. Performance of the hybrid rocket motor during flight and ground testing vs. initial simulation of the motor thrust curve, using data from thermochemical analysis.

Typical ILR-33 AMBER operations include transporting 98\% HTP to the launch site and use of a dedicated mobile setup for filling the oxidizer tank with $98 \%$ HTP. The oxidizer loading station was developed by Matyszewski and is shown in Figure 11. The launch sequence includes holding the rocket on the launch tower and ensuring that its hybrid motor undergoes its monopropellant mode duration (before fuel ignition) and reaches $3500 \mathrm{~N}$ of thrust. Only then, the two boosters are ignited and the launch control subsystem verifies the thrust level provided by the solid rocket motors. If the performance is as planned, the dedicated release mechanism moves away its two pivoted arms and allows lift-off. The Launch Management System (LMS) was developed by Kaniewski. Details on the LMS and the launch sequence are provided in [114]. While such subsystems on the launch tower are rare for small rockets, it was decided to use this approach in the case of the ILR-33 AMBER to enhance the reliability of the vehicle, since parallel staging is not common for modern vehicles of similar scale. Dynamics of the hybrid motor start-up phase with chamber pressure plots from flight testing can be seen in Figure 12. The pressure curve from the 2017 flight is different to the one from flights conducted in 2019. This is due to changes within the hybrid motor design (Mk2019). An image from the third flight of the ILR-33 AMBER rocket, where the maximum apogee to date was achieved, is presented in Figure 13. Notably, the launch was carried out at the seaside of the Baltic Sea and successful vehicle recovery was carried out from the sea surface [109]. 


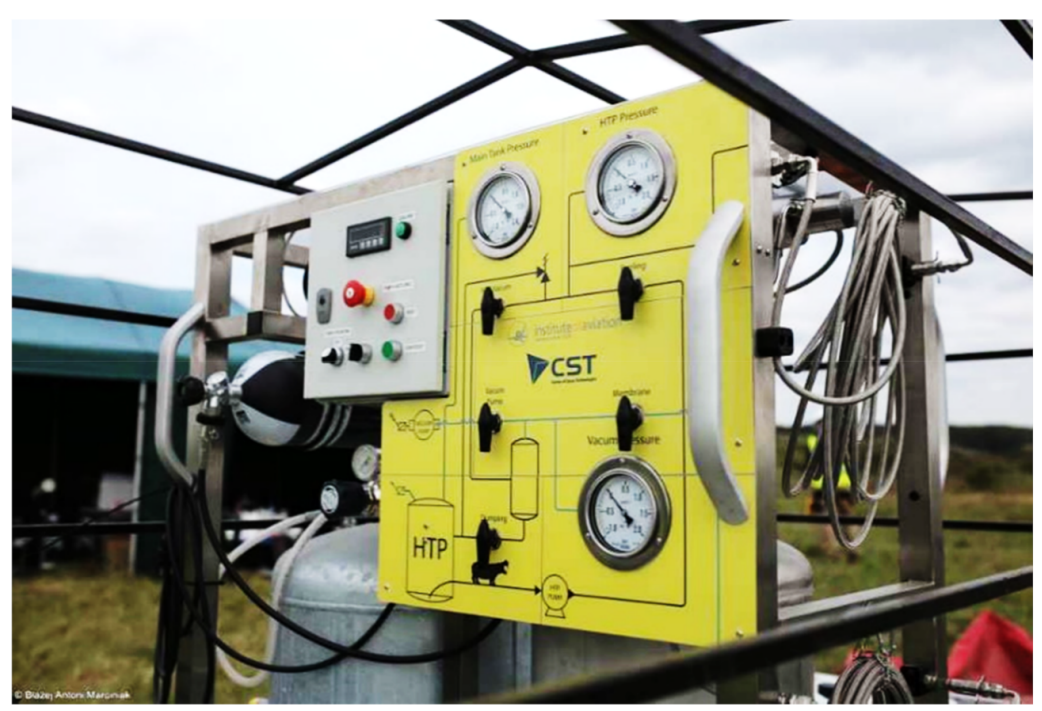

Figure 11. Mobile HTP loading station.

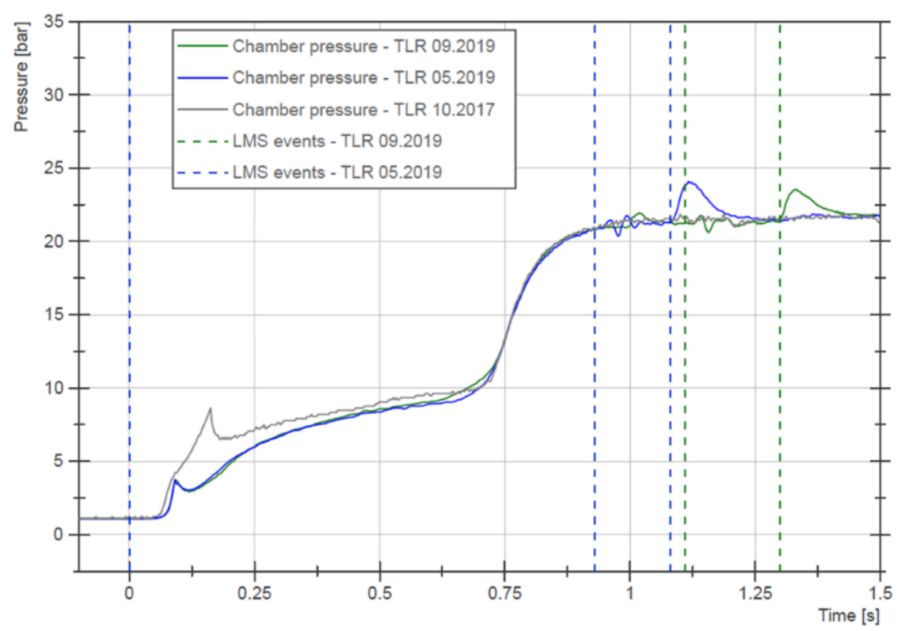

Figure 12. Hybrid rocket motor start-up during 3 in-flight test campaigns.

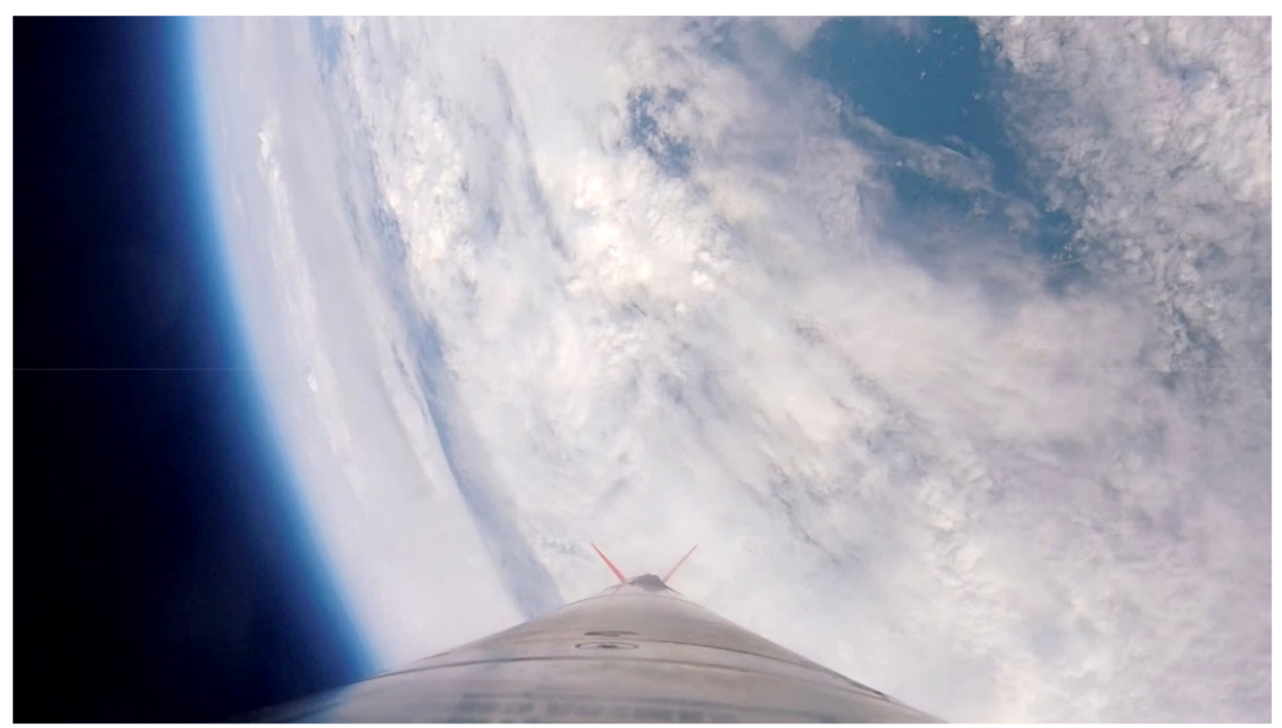

Figure 13. View from one of the on-board cameras of the ILR-33 AMBER rocket at $23 \mathrm{~km}$ [109]. 


\subsection{Other Actions}

During AMBER propulsion system developments, small-scale tests of new technologies for future applications have been undertaken. Additive manufacturing of fuel grains was led by Mayer and allowed prototyping of ABS, HDPE and PA6 grains. Results from example firings can be found in [44]. Fused deposition modeling technology was used. Subscale grain testing was completed using $98 \%$ HTP and the same catalyst as in the ILR-33 AMBER main motor $\left(\mathrm{Al}_{2} \mathrm{O}_{3} / \mathrm{Mn}_{\mathrm{x}} \mathrm{O}_{\mathrm{y}}\right)$. Firings with PA6 fuel gave the most stable and predictable characteristics (the thrust curve during hybrid combustion mode was closest to the design assumptions and the steady-state hybrid-mode operation pressure roughness was below $2 \%$ of the mean chamber pressure). HTP combined with PA6 also provides the highest theoretical specific impulse when compared to using other fuels from the study, namely ABS and HDPE, and it has higher theoretical performance than paraffin [44], which is widely considered due to its high burn rates. However, PA6 additive manufacturing technology up-scaling has not been approached, due to the difficult printing process and low relative grain density (an average of $94 \%$ of grain theoretical ideal density was achieved). Tests of grains with aluminum powder were also conducted, but initial tests showed combustion chamber instabilities.

\section{Discussion of Test Firing and Flight Testing Results}

Efficiencies exceeding $90 \%$ have been demonstrated during full-scale motor firings, in comparison to the first tests of 100 Newton motors, when $80 \%$ efficiency was obtained [99]. Flights allowed a velocity equivalent to Mach 2.05 and $23 \mathrm{~km}$ of altitude to be reached [109], while the AMBER 2K will exceed Mach 5 and $100 \mathrm{~km}$ of altitude. Altitudes reached to date were limited due to the small volume of oxidizer loading, test site size and the potential range of the fully loaded vehicle. Numerous tests allowed technology optimization. Good repeatability was demonstrated between consecutive subscale firings and also regarding the flight motor, including comparison of data from ground and flight campaigns. This considers thrust levels ( $1 \%$ of relative difference in thrust during hybrid mode operation when recalculated to sea-level conditions), as well as the delay between HTP flow initiation and hybrid-mode motor operation, which was below $1 \mathrm{~s}$. This delay is important regarding the vehicle's launch sequence and the loss of total impulse due to propulsion system monopropellant operation before hybrid mode. The motor chamber pressure build-up plots from all three AMBER rocket flights, provided in Figure 12, show that the differences in hybrid mode initiation in terms of pressure dynamics are not visible to the naked eye (the slight difference in monopropellant mode between different motor generations is not important since the rocket is not released by the Launch Management System until the predefined thrust level is reached). Lessons learned include the following points:

1. Subscale tests cannot be directly used for full-scale design and analysis (they shall be compensated for scale differences).

2. Careful measurement and data analysis is a must for obtaining reliable results for making valuable conclusions and design decisions.

3. HTP of $98 \%$ concentration allows for safe handling; however, special measures must be taken in order to ensure that organics are not in contact with HTP.

4. Hybrid rocket propulsion using $98 \%$ HTP can allow for efficient use for space transportation due to its higher performance than in the case of utilizing lower HTP concentrations (performance was verified in flight and extensive system performance data were obtained during in-flight and ground testing; 6-degree-of-freedom flight numerical simulations confirm that for full oxidizer loading of the ILR-33 AMBER 2K vehicle, flights above the Von Karman line will be possible).

Since 2017, the performance of the hybrid motor of the AMBER rocket has been gradually increased. The test-stand firing of the Mk2019+ demonstrated over $40 \mathrm{~s}$ burn duration of the ILR-33 AMBER rocket motor, which is equivalent to the requirement for reaching the Von Karman line (although a newer motor design will be used to maximize performance). While the same catalyst technology used may be implemented in larger space 
transportation propulsion systems, possibly with burn durations exceeding $100 \mathrm{~s}$, followon work will concentrate on enhancing the possible oxidizer mass flux and maintaining high decomposition efficiency for $98 \%$ HTP. Significantly longer burns (in the order of $1000 \mathrm{~s}$ ) using a single catalyst bed have been demonstrated at the Institute for low bed loadings; however, advances are needed for the most demanding applications, where large HTP throughputs are required. Different catalyst technologies are optimal for different propulsion applications. While this paper focused on the space transportation applications of HTP hybrids, the discussed propulsion technology may also be an attractive solution for in-space missions due to the stability and storability of HTP. Use of hybrid rocket motors on satellite platforms is possible; however, in the case of utilizing 98\% HTP, special attention has to be given to the catalyst bed lifetime in the case high burn durations, and high oxidizer throughputs are to be implemented. Further development may be needed for the most demanding applications.

\section{Conclusions}

The assumption that $98 \%$ HTP can be safely used as an oxidizer for hybrid rocket motors has been confirmed. Key advancements from nearly 10 years of work with hybrid rocket propulsion using 98\% HTP have been shown. The Lukasiewicz Research Network-Institute of Aviation in Warsaw, Poland has been the first entity to achieve several milestones concerning the use of $98 \%$ HTP, including its first use in a test-bench hybrid rocket motor (2012) and its in-flight use within a hybrid rocket motor (2017). The ILR-33 AMBER became the first known vehicle to demonstrate the use of $98 \%$ HTP. Success led to a total of 20 projects from the European Space Agency in the field of chemical propulsion (as of 2021), most of them linked to 98\% HTP. The findings of conducted research include scaling effects regarding transferring technology from subscale laboratory research to in-flight operations. Future plans involve launching the ILR-33 AMBER 2K rocket to higher altitudes, including missions above the Von Karman line, and optimizing its design concerning the effective integration of payloads and meeting potential customer needs. Further optimization of the hybrid rocket motor system is envisaged, although the burn duration of its Mk2019+ version already allows for reaching the $100 \mathrm{~km}$ altitude by the ILR-33 AMBER 2K rocket. Over a dozen patents have been obtained in the field of $98 \%$ HTP technology, hybrid rocket motor chamber technology and particular design features used in the AMBER design. The decade of advancements enabled Poland to be placed on the European map of space propulsion and space transportation developments, and green propulsion became the niche where the European Space Agency and commercial partners have seen the added value of Polish involvement. Several subsystems of the ILR-33 AMBER rocket, after adjustments, will be used with ESA, CNES and other French partners in the FROG vehicle (version FROG-H), which will demonstrate European capability in terms of vehicle vertical take-off and landing and Guidance Navigation and Control technology maturation. The propulsion system of FROG will use a throttleable monopropellant system [114]; however, its components shall be based on the hybrid propulsion system of AMBER.

Author Contributions: Conceptualization, A.O., P.S., P.W.; methodology, K.S., B.B., M.P., T.M., A.O., J.M. and P.S.; software, B.B., K.S., T.M. and A.O.; validation, P.S., T.M. and K.S.; investigation, P.S., B.B., G.R., K.S., D.K. and T.M.; data curation, P.S., K.S., T.M., J.M., D.K. and B.B., formal analysis, D.K., B.B., A.O. and J.M.; writing —original draft preparation, A.O.; writing—review and editing, A.O., P.S., M.P., B.B. and P.W.; visualization, M.P.; supervision, P.W., A.O., K.S. and M.P.; project administration, M.P., P.S., T.M.; funding acquisition, P.W., A.O. and M.P. All authors have read and agreed to the published version of the manuscript.

Funding: The presented experimental research was funded by the Lukasiewicz Research NetworkInstitute of Aviation (grant numbers 21832, 21935, 20003, 20016, 22111, 02320) and the paper was prepared within the "Space Research Development" project, financed by the Polish National Agency for Academic Exchange (No. PPI/APM/2018/1/00031/U/001) due to the potential of hybrid rocket technology for deorbiting spacecraft. 
Institutional Review Board Statement: Not applicable.

Informed Consent Statement: Not applicable.

Data Availability Statement: Not applicable.

Acknowledgments: The authors would like to express their gratitude to other team members of the Space Technology Department of the Lukasiewicz Research Network-Institute of Aviation for their extensive support. Special thanks go to members of the Chemistry Section, who support the daily handling of HTP and to members of the Technical Team, who support motor manufacturing and integration. Moreover, thanks should be given to Director Leszek Loroch and the rest of the Management of the Institute, who supported the hybrid technology development.

Conflicts of Interest: The authors declare no conflict of interest.

\section{References}

1. Karabeyoglu, A. Hybrid Rocket Propulsion for Future Space Launch. In Aeronautics and Astronautics 50th Year Anniversary; Space Propulsion Group Inc.: Sunnyvale, CA, USA, 2008.

2. Okninski, A. On use of hybrid rocket propulsion for suborbital vehicles. Acta Astronaut. 2018, 145, 1-10. [CrossRef]

3. Frota, O.; Ford, M. Review on Hybrid Propellants. ESA Spec. Publ. 2004, 557, 33.1.

4. Karabeyoglu, A. Challanges in the Development of Large-Scale Hybrid Rockets. Int. J. Energ. Mater. Chem. Propuls. 2017, 16, 243-261. [CrossRef]

5. Mukunda, H.S.; Jain, V.K.; Paul, P.J. A review of hybrid rockets: Present status and future potential. Proc. Indian Acad. Sci. Sect. C Eng. Sci. 1979, 2, 215-242.

6. Altman, D. Hybrid rocket development history. In Proceedings of the 27th Joint Propulsion Conference, Sacramento, CA, USA, 24 June 1991.

7. Altman, D.; Holzman, A. Overview and history of hybrid rocket propulsion. Prog. Astronaut. Aeronaut. $2007,218,1$.

8. Calabro, M. Overview on hybrid propulsion. Progr. Propuls. Phys. 2011, 2, 353-374.

9. AIAA. Fundamentals of Hybrid Rocket Combustion and Propulsion; Kuo, K.K., Chiaverini, M.J., Eds.; American Institute of Aeronautics and Astronautics: Reston, VA, USA, 2007; ISBN 978-1563477034.

10. Carmicino, C. Special Issue "Advances in Hybrid Rocket Technology and Related Analysis Methodologies". Aerospace 2019, 6, 128. [CrossRef]

11. Marquardt, T.; Majdalani, J. Encouraging Tests of Hybrids Hold Hope of Safer, Reliable Access to Space; AIAA: Reston, VA, USA, 2020; p. 53.

12. Schmierer, C.; Kobald, M.; Tomilin, K.; Fischer, U.; Schlechtriem, S. Low cost small-satellite access to space using hybrid rocket propulsion. Acta Astronaut. 2019, 159, 578-583. [CrossRef]

13. Macklin, F.; Grainger, C.; Veno, M.; Benson, J. New Applications for Hybrid Propulsion. In Proceedings of the 39th AIAA/ASME/SAE/ASEE Joint Propulsion Conference and Exhibit, Huntsville, Alabama, 20-23 July 2003.

14. Jens, E.T.; Cantwell, B.J.; Hubbard, G.S. Hybrid rocket propulsion systems for outer planet exploration missions. Acta Astronaut. 2016, 128, 119-130. [CrossRef]

15. Chandler, A.A.; Cantwell, B.J.; Scott Hubbard, G.; Karabeyoglu, A. Feasibility of a single port Hybrid Propulsion system for a Mars Ascent Vehicle. Acta Astronaut. 2011, 69, 1066-1072. [CrossRef]

16. Parissenti, G.; Pessana, M.; Gaia, E.; Zaccagnino, E.; Santilli, F.; Pavarin, D.; Bettella, A.; Ronningen, J.-E.; Van Put, P.; Tijsterman, R. Throttleable hybrid engine for planetary soft landing. In Proceedings of the 4 th European Conference for Aerospace Sciences (EUCASS 2011), Saint Petersburg, Ruassia, 4-8 July 2011.

17. Whitmore, S.A.; Merkley, S.L.; Spurrier, Z.S.; Walker, S.D. Development of a Power Efficient, Restartable, "Green" Propellant Thruster for Small Spacecraft and Satellites. In Proceedings of the Small Satellite Conference, Logan, UT, USA, 10-13 August 2015.

18. Lips, H.R. Experimental Investigation on Hybrid Rocket Engines Using Highly Aluminized Fuels. J. Spacecr. Rockets 1977, 14, 539-545. [CrossRef]

19. Ciezki, H.; Werling, L.; Negri, M.; Strauss, F.; Kobald, M.; Kirchberger, C.; Freudenmann, D.; Hendrich, C.; Wilhelm, M.; Petrarolo, A.; et al. 50 Years of Test Complex M11 in Lampoldshausen Research on Space Propulsion Systems for Tomorrow. In Proceedings of the 7th European Conference for Aeronautics and Space Sciences (EUCASS 2017), Milan, Italy, 3-6 July 2017; pp. 3-6. [CrossRef]

20. Kaniewski, D.; Bartkowiak, B.; Matyszewski, J.; Marciniak, B.; Pakosz, M.; Nowakowski, P.; Okninski, A.; Cieslinski, D.; Rysak, D.; Skorski, M.; et al. Flight Test of the Hybdrid Rocket Propulsion System-Lessons Learned from ILR-33 Project; Association Aéronautique et Astronautique de France: Seville, Spain, 2018; Volume SP2018_357.

21. Chen, Y.-S.; Wu, B. Development of a Small Launch Vehicle with Hybrid Rocket Propulsion. In Proceedings of the 2018 Joint Propulsion Conference, Cincinnati, OH, USA, 9-11 July 2018.

22. Seedhouse, E. SpaceShipTwo: VSS Enterprise. In Virgin Galactic; Springer: Berlin, Germany, 2015; pp. $65-85$.

23. Paper Information (42082)_IAF. Available online: https://iafastro.directory/iac/paper/id/42082/summary/ (accessed on 8 August 2021). 
24. Schüttauf, K.; Stamminger, A.; Lappöhn, K.; Ciezki, H.; Kitsche, W. Operation of solid rockets in comparison with hybrid rockets during the STERN project. In Proceedings of the SpaceOps 2016 Conference, Daejeon, Korea, 16-20 May 2016.

25. Campbell, J.; Macklin, F.; Thicksten, Z. Handling Considerations of Nitrous Oxide in Hybrid Rocket Motor Testing. In Proceedings of the 44th AIAA/ASME/SAE/ASEE Joint Propulsion Conference \& Exhibit, Hartford, CT, USA, 21-23 July 2008.

26. Karabeyoglu, M.A. Nitrous Oxide and Oxygen Mixtures (Nytrox) as Oxidizers for Rocket Propulsion Applications. J. Propuls. Power 2014, 30, 696-706. [CrossRef]

27. Ventura, M. Long Term Storability of Hydrogen Peroxide. In Proceedings of the 41st AIAA/ASME/SAE/ASEE Joint Propulsion Conference \& Exhibit, Tucson, AZ, USA, 10-13 July 2005.

28. Sutton, G.P.; Biblarz, O. Rocket Propulsion Elements; John Wiley \& Sons: New York, NY, USA, 2016.

29. Rarata, G.; Rokicka, K.; Surmacz, P. Hydrogen Peroxide as a High Energy Compound Optimal for Propulsive Applications. Cent. Eur. J. Energ. Mater. 2016, 13, 778-790. [CrossRef]

30. Wernimont, E.; Ventura, M.; Garboden, G.; Mullens, P. Past and Present Uses of Rocket Grade Hydrogen Peroxide; General Kinetics, LLC.: Aliso Viejo, CA, USA, 1999.

31. Moore, G.E.; Berman, K. A Solid-Liquid Rocket Propellant System. J. Jet Propuls. 1956, 26, 965-968. [CrossRef]

32. Wernimont, E.J.; Meyer, S.E. Hydrogen Peroxide Hybrid Rocket Engine Performance Investigation. In Proceedings of the 30th AIAA Joint Propulsion Conference and Exhibit, Indianapolis, IN, USA, 27-29 June 1994. [CrossRef]

33. Božić, O.; Porrmann, D.; Lancelle, D.; Hartwig, A. Program AHRES and its contribution to assess features and current limitations of hybrid rocket propulsion. In Proceedings of the 63th Congress of International Astronautical Federation, IAC-12-C4, Naples, Italy, 1-5 October 2012; Volume 2.

34. Osmon, R.V. An experimental investigation of a lithium aluminum hydride- Hydrogen peroxide hybrid rocket(Combustion and performance characteristics of lithium aluminum hydride/hydrogen peroxide hybrid rocket). In Chemical Engineering Progress; Symposium Series; American Institute of Chemical Engineers: New York, NY, USA, 1966; pp. 92-102.

35. Heister, S.D.; Wernimont, E.J.; Rusek, J. High test peroxide hybrid rocket research. In Proceedings of the 1st Hydrogen Peroxide Propulsion Workshop, Univeristy of, Surrey, Surrey, UK, 29-31 July 1998.

36. Gilmour Space Passes First Orbital Engine Tests, Aims for Suborbital Launch in 2018ISpaceTech Asia. Available online: https:/ / www.spacetechasia.com/gilmour-space-passes-first-orbital-engine-tests-aims-for-suborbital-launch-in-2018/ (accessed on 8 August 2021).

37. Tian, H.; Li, X.; Zeng, P.; Yu, N.; Cai, G. Numerical and experimental studies of the hybrid rocket motor with multi-port fuel grain. Acta Astronaut. 2014, 96, 261-268. [CrossRef]

38. Lestrade, J.-Y.; Anthoine, J.; Musker, A.J.; Lecossais, A. Experimental demonstration of an end-burning swirling flow hybrid rocket engine. Aerosp. Sci. Technol. 2019, 92,1-8. [CrossRef]

39. Porrmann, D.; Wilken, J.; Bozic, O.; Lancelle, D. First Results of Regression Rate Measurements on Ultrasonic Basis in the Ahres Hybrid Rocket Motor. In Proceedings of the Space Propulsion, Köln, Germany, 19-22 May 2014.

40. Santi, M.; Paccagnella, E.; Ruffin, A.; Barato, F.; Pavarin, D.; Misté, G.; Venturelli, G.; Bellomo, N. Development and Testing of a Long Burning Time Lab-scale Paraffin-based Hybrid Rocket Motor. In Proceedings of the 53rd AIAA/SAE/ASEE Joint Propulsion Conference, Atlanta, GA, USA, 10-12 July 2017.

41. Castaneda, D.A.; Natan, B. Experimental investigation of the hydrogen peroxide—solid hydrocarbon hypergolic ignition. Acta Astronaut. 2019, 158, 286-295. [CrossRef]

42. Tsujikado, N.; Koshimae, M.; Ishikawa, R.; Kitahara, K.; Ishihara, A.; Sakai, Y. An Application of Commercial Grade Hydrogen Peroxide for Hybrid/Liquid Rocket Engine. In Proceedings of the 38th AIAA/ASME/SAE/ASEE Joint Propulsion Conference \& Exhibit, Indianapolis, Indiana, 26 June 2002.

43. Faenza, M.; Boiron, A.J.; Haemmerli, B.; Verberne, C.J. Development of the Nucleus Hybrid Propulsion System: Enabling A Successful Flight Demonstration. In Proceedings of the AIAA Propulsion and Energy 2019 Forum, Indianapolis, IN, USA, 19-22 August 2019.

44. Mayer, T.; Bartkowiak, B. Scalability Analysis of Additively Manufactured Grain for 4 kN High Test Peroxide Hybrid Rocket Motor. In Proceedings of the 8th European Conference for Aeronautics and Space Sciences (EUCASS), Madrid, Spain, 4 July 2019; pp. 1-12.

45. Ahn, B.; Huh, J.; Bhosale, V.K.; Kwon, S. Three-Dimensionally Printed Polylactic Acid as Solid Fuel for Hydrogen Peroxide Hybrid Rockets. J. Propuls. Power 2021, 37, 171-175. [CrossRef]

46. Technology I ARRC. Available online: https: / / arrc.tw/technology/ (accessed on 8 August 2021).

47. SKYHY Rocket I Skyrora. Available online: https:/ / www.skyrora.com/skyhy (accessed on 8 August 2021).

48. Whitmore, S.A.; Martinez, C.J.; Merkley, D.P. Catalyst development for an arc-ignited hydrogen peroxide/ABS hybrid rocket system. Aeronaut. Aerosp. Open Access J. 2018, 2, 356-388. [CrossRef]

49. Lestrade, J.-Y.; Anthoine, J.; Verberne, O.; Boiron, A.J.; Khimeche, G.; Figus, C. Experimental Demonstration of the Vacuum Specific Impulse of a Hybrid Rocket Engine. J. Spacecr. Rockets 2017, 54, 101-108. [CrossRef]

50. Zhao, B.; Yu, N.; Liu, Y.; Zeng, P.; Wang, J. Unsteady simulation and experimental study of hydrogen peroxide throttleable catalyst hybrid rocket motor. Aerosp. Sci. Technol. 2018, 76, 27-36. [CrossRef]

51. Li, C.; Cai, G.; Wang, P.; Tian, H. Flow field and injector heat characteristics of hybrid rocket motor with annular-gap injector. Aerosp. Sci. Technol. 2019, 93, 105326. [CrossRef] 
52. Jeong, J.; Bhosale, V.K.; Kwon, S. Ultrafast igniting, low toxicity hypergolic hybrid solid fuels and hydrogen peroxide oxidizer. Fuel 2021, 286, 119307. [CrossRef]

53. Whitmore, S.A.; Armstrong, I.W.; Heiner, M.C.; Martinez, C.J. High-Performing Hydrogen Peroxide Hybrid Rocket with 3-D Printed and Extruded ABS Fuel. In Proceedings of the 2018 Joint Propulsion Conference, Cincinnati, OH, USA, 9-11 July 2018.

54. Oztan, C.; Coverstone, V. Utilization of additive manufacturing in hybrid rocket technology: A review. Acta Astronaut. 2021, 180, 130-140. [CrossRef]

55. Knuth, W.H.; Chiaverini, M.J.; Sauer, J.A.; Gramer, D.J. Solid-Fuel Regression Rate Behavior of Vortex Hybrid Rocket Engines. J. Propuls. Power 2002, 18, 600-609. [CrossRef]

56. Kang, S.; Lee, D.; Lee, E.; Kwon, S. Design and performance evaluation of hybrid rocket using 95 wt. \% H2O2. In Proceedings of the 52nd AIAA/SAE/ASEE Joint Propulsion Conference, Salt Lake City, UT, USA, 25-27 July 2016.

57. Ahn, B.; Kang, H.; Lee, E.; Yun, Y.; Kwon, S. Design of Multiport Grain with Hydrogen Peroxide Hybrid Rocket. J. Propuls. Power 2018, 34, 1189-1197. [CrossRef]

58. Farbar, E.; Louwers, J.; Kaya, T. Investigation of Metallized and Nonmetallized Hydroxyl Terminated Polybutadiene/Hydrogen Peroxide Hybrid Rockets. J. Propuls. Power 2007, 23, 476-486. [CrossRef]

59. Akiba, R.; Nakajima, T.; Nagata, H. A New Era of the Hybrid Rocket. J. Space Technol. Sci. 2000, 16, 2.1-2.5.

60. DeLuca, L.T.; Bernelli, F.; Maggi, F.; Tadini, P.; Pardini, C.; Anselmo, L.; Grassi, M.; Pavarin, D.; Francesconi, A.; Branz, F.; et al. Active space debris removal by a hybrid propulsion module. Acta Astronaut. 2013, 91, 20-33. [CrossRef]

61. Lécossais, A.; Odic, K.; Fiot, D.; Lestrade, J.-Y.; Verberne, O.; Fernando, P.; Christ, P.; Searle, T. HYPROGEO Hybrid Propulsion: Latest project achievements. In Proceedings of the Space Propulsion 2018, Seville, Spain, 14-18 May 2018.

62. Clark, J.D.; Asimov, I. Ignition!: An Informal History of Liquid Rocket Propellants; Rutgers University Press: New Brunswick, NJ, USA, 1972; ISBN 978-0-8135-9919-9.

63. Pakosz, M.; Noga, T.; Kaniewski, D.; Okninski, A.; Bartkowiak, B. ILR-33 AMBER rocket-quick, low cost and dedicated access to suborbital flights for small experiments. In Proceedings of the 24th ESA Symposium on European Rocket and Balloon Programmes and Related Research, Essen, Germany, 16-20 June 2019.

64. Cieśliński, D.; Okninski, A.; Noga, T.; Pakosz, M.; Mayer, T.; Kaniewski, D.; Florczuk, W.; Surmacz, P.; Bartkowiak, B.; Wolanski, P. ILR-33 "Amber" Rocket-A Platform For Microlauncher System Technology Development. In Proceedings of the 69th International Astronautical Congress 2018, Bremen, Germany, 1-5 October 2018.

65. Ventura, M.C.; Heister, S.D. Hydrogen peroxide as an alternate oxidizer for a hybrid rocket booster. J. Propuls. Power 1995, 11, 562-565. [CrossRef]

66. Lund, G.; Starrett, W.; Jensen, K. Development and lab-scale testing of a gas generator hybrid fuel in support of the Hydrogen Peroxide Hybrid Upper Stage Program. In Proceedings of the 37th Joint Propulsion Conference and Exhibit, Salt Lake City, UT, USA, 8-11 July 2001.

67. Miranda, F. Design Optimization of Ground and Air-Launched Hybrid Rockets; Delft University of Technology: Delft, The Netherlands, 2015.

68. Costa, F.; Contaifer, R.; Albuquerque, J.; Gabriel, S.; Marques, R. Study of Paraffin $/ \mathrm{H}_{2} \mathrm{O}_{2}$ Hybrid Rockets for Launching Nanosats. In Proceedings of the 44th AIAA/ASME/SAE/ASEE Joint Propulsion Conference \& Exhibit, Hartford, CT, USA, 21-23 July 2008.

69. 90 Kilonewton Hotfire from Gilmour Space Technologies I Spaceaustralia. Available online: https://spaceaustralia.com/index php/news/90-kilonewton-hotfire-gilmour-space-technologies (accessed on 8 August 2021).

70. Messinger, T.L. Conceptual Design and Optimization of Hybrid Rockets. Master's Thesis, Schulich School of Engineering, Calgary, AB, Canada, 2021.

71. Current Programs \& Technology Development Areas-Parabilis-Space. Available online: https://parabilis-space.com/programsand-applications/\#hybrid-upper-stage (accessed on 8 August 2021).

72. Brown, T.R.; Lydon, M.C. Testing of Paraffin-Based Hybrid Rocket Fuel Using Hydrogen Peroxide Oxidizer. In Proceedings of the AIAA Region 5 Student Conference, Wichita, KS, USA, 14-16 September 2005.

73. Whitmore, S.A.; Merkley, D.P. Arc-Ignition of a 70\%-85\% Hydrogen Peroxide/ABS Hybrid Rocket System. In Proceedings of the 53rd AIAA/SAE/ASEE Joint Propulsion Conference, Atlanta, GA, USA, 10-12 July 2017.

74. Wernimont, E.J.; Heister, S.D. Combustion Experiments in Hydrogen Peroxide/Polyethylene Hybrid Rocket with Catalytic Ignition. J. Propuls. Power 2000, 16, 318-326. [CrossRef]

75. Bozic, O.; Poppe, G.; Porrmann, D. An Advanced Hybrid Rocket Engine for an Alternative Upper Stage of the Brasilian VLM 1 LEO Launcher. In Proceedings of the 65th International Astronautical Congress, Toronto, ON, Canada, 29 September 2014.

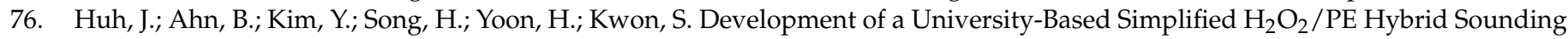
Rocket at KAIST. Int. J. Aeronaut. Space Sci. 2017, 18, 512-521. [CrossRef]

77. Cai, G.; Zeng, P.; Li, X.; Tian, H.; Yu, N. Scale effect of fuel regression rate in hybrid rocket motor. Aerosp. Sci. Technol. 2013, 24, 141-146. [CrossRef]

78. Wu, Y.; Yu, X.; Lin, X.; Li, S.; Wei, X.; Zhu, C.; Wu, L. Experimental investigation of fuel composition and mix-enhancer effects on the performance of paraffin-based hybrid rocket motors. Aerosp. Sci. Technol. 2018, 82-83, 620-627. [CrossRef]

79. Shark, S.C.; Pourpoint, T.L.; Son, S.F.; Heister, S.D. Performance of Dicyclopentadiene $/ \mathrm{H}_{2} \mathrm{O}_{2}$-Based Hybrid Rocket Motors with Metal Hydride Additives. J. Propuls. Power 2013, 29, 1122-1129. [CrossRef] 
80. Tsohas, J.; Droppers, L.J.; Glean, E.; Dambash, E.M.; Heister, S.D. Progress in technology demonstration for a small hybrid launch vehicle. In Proceedings of the 5th Responsive Space Conference, Los Angeles, CA, USA, 23-26 April 2007.

81. Paccagnella, E.; Santi, M.; Ruffin, A.; Barato, F.; Pavarin, D.; Misté, G.A.; Venturelli, G.; Bellomo, N. Testing of a Long-Burning-Time Paraffin-Based Hybrid Rocket Motor. J. Propuls. Power 2019, 35, 432-442. [CrossRef]

82. Franco, M.; Barato, F.; Paccagnella, E.; Santi, M.; Battiston, A.; Comazzetto, A.; Pavarin, D. Regression Rate Design Tailoring through Vortex Injection in Hybrid Rocket Motors. J. Spacecr. Rockets 2020, 57, 278-290. [CrossRef]

83. Cai, G.; Zhu, H.; Rao, D.; Tian, H. Optimal design of hybrid rocket motor powered vehicle for suborbital flight. Aerosp. Sci. Technol. 2013, 25, 114-124. [CrossRef]

84. Li, X.; Tian, H.; Yu, N.; Cai, G. Experimental investigation of fuel regression rate in a HTPB based lab-scale hybrid rocket motor. Acta Astronaut. 2014, 105, 95-100. [CrossRef]

85. Cai, G.; Li, C.; Tian, H. Numerical and experimental analysis of heat transfer in injector plate of hydrogen peroxide hybrid rocket motor. Acta Astronaut. 2016, 128, 286-294. [CrossRef]

86. Surmacz, P. Influence of various types of Al2O3/MnxOy catalysts on performance of a 100mm chamber for decomposition of 98\%+ hydrogen peroxide. Trans. Inst. Aviat. 2015, 240, 58-68. [CrossRef]

87. Surmacz, P.; Rarata, G. Prace badawcze i rozwojowe nad demonstratorem technologii rakietowego silnika hybrydowego wykorzystujacego 98\% nadtlenek wodoru jako utleniacz. Prace Instytutu Lotnictwa 2014, 240, 51-61. [CrossRef]

88. Gordon, S.; Mcbride, B.J. Computer program for calculation of complex chemical equilibrium compositions and applications. Part 1: Analysis. NASA Ref. Publ. 1994, 1311, 49.

89. MatlabCEA; Purdue University, Purdue Hydrogen Systems Lab: West Lafayette, IN, USA, 2019.

90. Runckel, J.F.; Willis, C.M.; Salters, L.B. Investigation of Catalyst Beds for 98-Percent-Concentration Hydrogen Peroxide; National Aeronautics and Space Administration: Washington, DC, USA, 1963.

91. Rarata, G.; Surmacz, P.; Sobczak, K. Near Future Green Propellant for Space Transportation. In Proceedings of the VIII International Scientific Conference: "Development Trends in Space Propulsion Systems", Warsaw, Poland, 14-15 November 2013; Volume 277.

92. McCormick, J.C.; Lijewski, A.; Carnine, G. Storage of $90 \%$ and $98 \%$ by Weight Hydrogen Peroxide in Sealed Containers for Extended Periods; Food Machinery and Chemical Corp Becco Chemical Div: Buffalo, NY, USA, 1961.

93. Quinn, J. Oxidizer Selection for the ISTAR Program (Liquid Oxygen versus Hydrogen Peroxide). In Proceedings of the 38th AIAA/ASME/SAE/ASEE Joint Propulsion Conference \& Exhibit, Indianapolis, IN, USA, 26 June 200.

94. Rarata, G.; Florczuk, W. Safety aspects of hypergolic propellants with hydrogen peroxide. Mater. Wysokoenergetyczne 2017, 9, 136-144. [CrossRef]

95. Wolanski, P.; Folusiak, M.; Kublik, D.; Swiderski, K.; Rarata, G.; Sobczak, K.; Surmacz, P.; Florczuk, W. Techniques and Technologies of Space Rockets; Institute of Aviation: Warsaw, Poland, 2009; Available online: https:/ /www.researchgate.net/publication/236577 067_Techniques_and_technologies_of_space_rockets (accessed on 24 August 2021).

96. Wolanski, P. Hybrydy silniki rakietowe na paliwo ciekło-stałe. Skrzyd. Pol. 1965, 90, 10-11.

97. Rarata, G.; Surmacz, P.; Swiderski, K.; Folusiak, M.; Kindracki, J.; Wolanski, P. The model hybrid rocket motor. Computations, design and fire tests. Inf. Syst. Inf. Syst. Mech. Control Sci. Tech. Collect. 2009, 3, 69-73.

98. Surmacz, P.; Rarata, G.; Wolanski, P. Development of a Hybrid Propulsion System for Attitude Control and Orbit Change of Small Satellites. In NATO AVT 171 Multifunctional Structures and Systems Technologies for Small Spacecraft; NATO: Brussels, Belgium, 2010.

99. Surmacz, P.; Rarata, G. Investigation of spontaneous ignition in a $100 \mathrm{~N}$ HTP/HTPB hybrid rocket engine. Trans. Inst. Aviat. 2015, 240, 69-79. [CrossRef]

100. Wisniowski, W.; Wolanski, P. The role of the institute of aviation in space technology research. Trans. Inst. Aviat. 2014, 234, 9-16. [CrossRef]

101. Marciniak, B.; Okniński, A. Rozwój polskiego programu niewielkich rakiet sondujących. Pract. Inst. Lotnictwa 2014, 234, 82-89. [CrossRef]

102. Okninski, A.; Marciniak, B.; Bartkowiak, B.; Kaniewski, D.; Matyszewski, J.; Kindracki, J.; Wolanski, P. Development of the Polish Small Sounding Rocket Program. Acta Astronaut. 2015, 108, 46-56. [CrossRef]

103. Marciniak, B.; Okninski, A.; Bartkowiak, B.; Pakosz, M.; Sobczak, K.; Florczuk, W.; Kaniewski, D.; Matyszewski, J.; Nowakowski, P.; Cieslinski, D.; et al. Development of the ILR-33 "Amber" sounding rocket for microgravity experimentation. Aerosp. Sci. Technol. 2018, 73, 19-31. [CrossRef]

104. Okninski, A.; Bartkowiak, B.; Sobczak, K.; Kublik, D.; Surmacz, P.; Rarata, G.; Marciniak, B.; Wolanski, P. Development of a Small Green Bipropellant Rocket Engine Using Hydrogen Peroxide as Oxidizer. In Proceedings of the 50th AIAA/ASME/SAE/ASEE Joint Propulsion Conference, Cleveland, OH, USA, 28-30 July 2014.

105. Sobczak, K.M.; Surmacz, P.; Bartkowiak, B.; Okninski, A.; Rarata, G.P.; Wolanski, P.; Kublik, D.; Valencia Bel, F. Test Campaign of a Green Liquid Bi-propellant Rocket Engine Using Catalytically Decomposed 98\% Hydrogen Peroxide as Oxidizer. In Proceedings of the 53rd AIAA/SAE/ASEE Joint Propulsion Conference, Atlanta, GA, USA, 10-12 July 2017.

106. Surmacz, P.; Sobczak, K.; Bartkowiak, B.; Rarata, G.; Okninski, A.; Mayer, T.; Wolanski, P.; Bel, V. Development Status of 500 N-class HTP/TMPDA Bi-propellant Rocket Engine. In Proceedings of the 69th International Astronautical Congress, Bremen, Germany, 1-5 October 2018. 
107. Surmacz, P.; Kostecki, M.; Gut, Z.; Olszyna, A. Aluminum Oxide-Supported Manganese Oxide Catalyst for a $98 \%$ Hydrogen Peroxide Thruster. J. Propuls. Power 2019, 35, 614-623. [CrossRef]

108. Surmacz, P.; Rarata, G.P.; Sobczak, K.M.; Bartkowiak, B.; Okninski, A.; Wolanski, P.; Valencia Bel, F. Experimental Evaluation of a Catalyst Bed Based on $\mathrm{Mn}_{\mathrm{x}} \mathrm{O}_{\mathrm{y}} / \mathrm{Al}_{2} \mathrm{O}_{3}$ Catalyst for Decomposition of $98 \%$ Hydrogen Peroxide. In Proceedings of the 53rd AIAA/SAE/ASEE Joint Propulsion Conference, Atlanta, GA, USA, 10-12 July 2017.

109. Okninski, A.; Pakosz, M.; Bartkowiak, B.; Nowakowski, P.; Noga, T.; Matyszewski, J.; Cieslinski, D.; Marciniak, B.; Kaniewski, D.; Wolanski, P. The ILR-33 AMBER 2K Rocket-Dedicated Access to Suborbital Experimentation; International Astronautical Fedration: Washington, DC, USA, 2019; Volume IAC-19,D2,6,8,x50868.

110. Nowakowski, P.; Okninski, A.; Pakosz, M.; Cieslinski, D.; Bartkowiak, B.; Wolanski, P. Development of small solid rocket boosters for the ILR-33 sounding rocket. Acta Astronaut. 2017, 138, 374-383. [CrossRef]

111. Spiralski, M.; Bęben, K.; Konior, W.; Cieśliński, D. High Altitude Ballooning as an Atmospheric Sounding System in the Pre-Flight Procedures of ILR-33 Amber. Trans. Aerosp. Res. 2020, 2020, 66-77. [CrossRef]

112. Pakosz, M.; Matysek, K.; Nowakowski, P.; Noga, T.; Majewska, E.; Ptasinski, G. Design Modifications for Performance Enhancement of a Suborbital Rocket ILR-33 Amber 2K. In Proceedings of the 71st International Astronautical Congress (IAC)-The CyberSpace Edition, Guido, Schwartz, 12-14 October 2020; Volume IAC-20-D2.6.7.

113. Ruchala, P.; Placek, R.; Stryczniewicz, W.; Matyszewski, J.; Cieslinski, D.; Bartkowiak, B. Wind tunnel investigation of the influence of boosters and fins on aerodynamic characteristics of ILR-33 Amber rocket. Trans. Aerosp. Res. 2017, 2017, 82-102. [CrossRef]

114. Rmili, B.; Monchaux, D.; Boisneau, O.; Hassin, J.; Querry, S.; Besson, S.; Poirey, G.; Bore, R.; Hamada, I.; Amrouchi, H.; et al. FROG, a Rocket for GNC demonstrations: Firsts flights attempts of the FROG turbojet version and preparation of the future mono-propellant rocket engine. In Proceedings of the 8th European Conference for Aeronautics and Space Sciences, Madrid, Spain, 1-4 July 2019. [CrossRef] 